「宗族」研究と中国法制史学——近五十年来の動向

集男

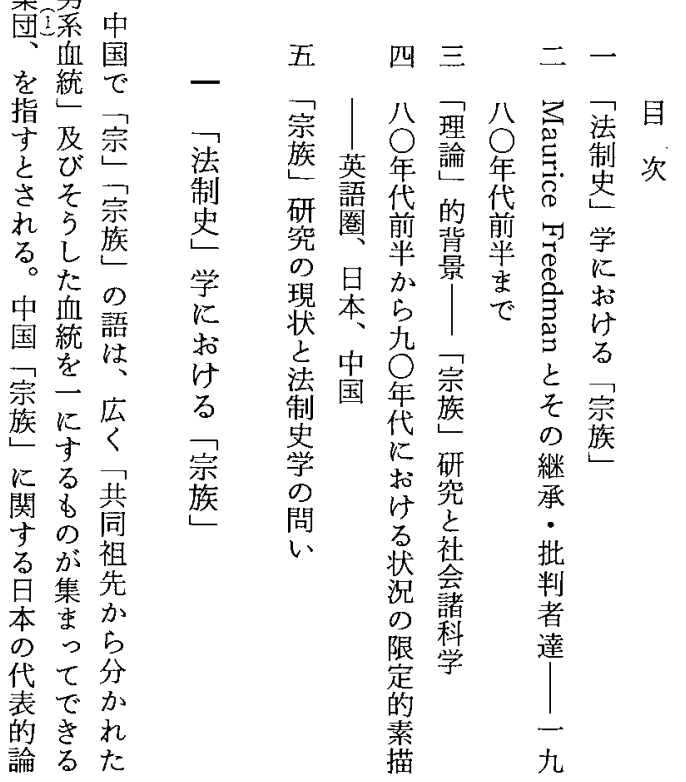

にてま味課的らす関で抽ま確強者 研一たし題なにる心あ象でないの 究宗実、と課即言のる的以系機— 者族際どす題し語対。に样譜能人

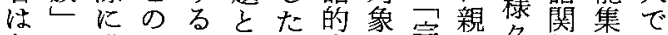
各々発上とな子実之宗族々係団ま 々称せ 5 るる宗践な族のなにかる のさらに、。族、る 摡力種よら瀬

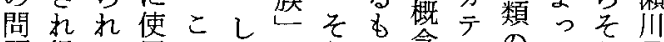

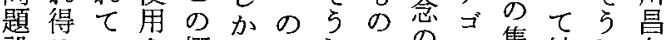
設るいさ概し理しでのリ集結し久

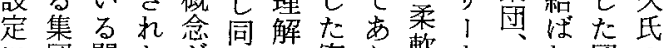
に団問たが時は策り軟を西れ団の 応のいか歴に践、性的更た体言 し具の、史、它多は指に多性 乙体、と社宗行様二示はの袁如

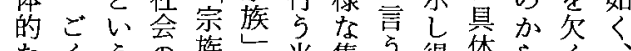

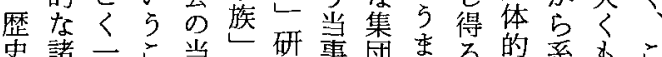

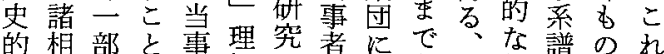
概にには者解にのら極集関まは 念分過可にを牤観きな団係で と析ぎ能と現い念同くてにの団 しをななっ代て世でそ柔限噯あ体 て加以問ての最界語片軟ら昧る的 の艺。題何学あ、で自なずない性 马そ群を問基こ表体概 ヨ。は格 宗際し意的本れ現が念りの明の

宗

族

研

究

と

中

国

法

制

史

学

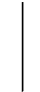

近

五

十

年

来

の

動

向 
合財矛留る理す用 同産係念のし 居等的でて宗共れ期宗乱 共と如秩あ生に虐る中族暴

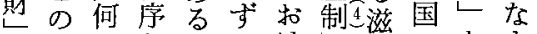
の関にたしるけし賀のをま 単係整ると諸る概秀取と

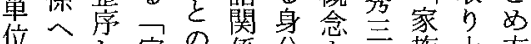
妾のし宗課係分を在族上方

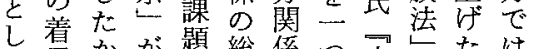
て自かか題総係つ市詢た のはま設定体㤎の国を文あ

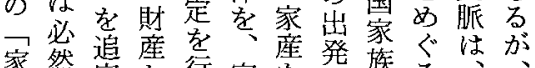
家然究た行家を点法る、

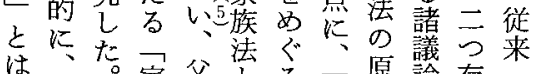
区具。家父々る戠論存口 別具こ應系し共本理を在法 的の親て同書心二し制

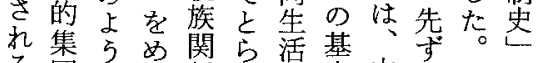
る団なぐ係党之本中収学

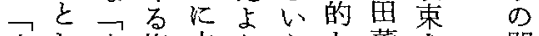
宗し宗権立 $55 な$ 薰さ問 族て利脚と場立氏世 产のと義すすに場のた関
か 明な在対再究

ら確るし象構の本|等

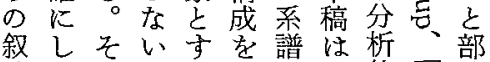
述なれ以べ貝に主的闹分

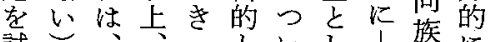

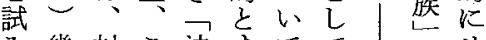

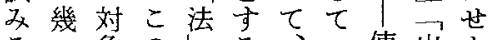
るつ象の方正使出上 たか、観が。中九用自重 めの問点如無国五し集な の研題自何論口○て団る 便究設体な弪年き为 宜に定多る何制代て高の

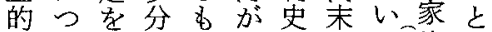
ない必法法族し 多て守主加制学 5 。組七 の、し観、史の現織巨 に或 b的一学関在 過る共な般で心に等

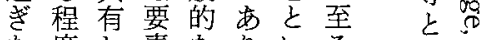
な度し素なりいるる

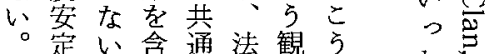

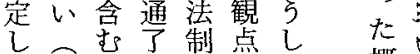
た或こ解製点した 概导

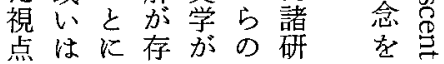

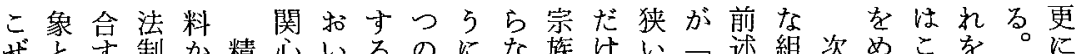

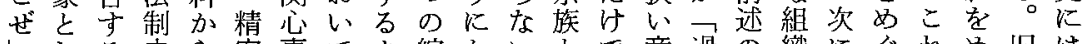
七しる史ら密事てよ綜かいとで意過の織にぐれめ旧は にてこ学着なとつら合か。村は味去、以、っらぐくそ 寸いとの奏問な宗に的わし落足の䆥中国て構っはれ

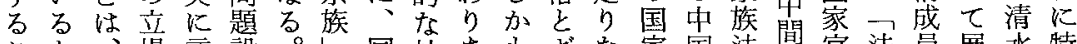
$こ と$ 場言設。国社あすギな家国法间官法員展水特

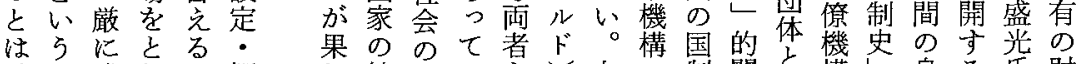

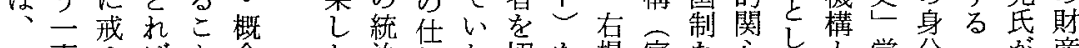
一事めば之念た治組た切を揭官な心七学分分交産

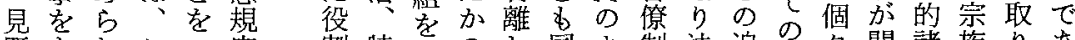

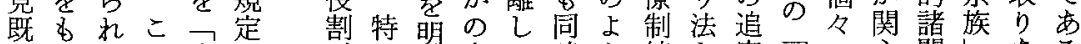
成っるれ実か がにら点て時

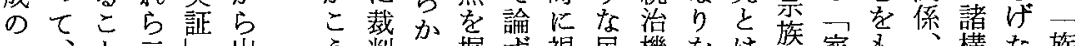

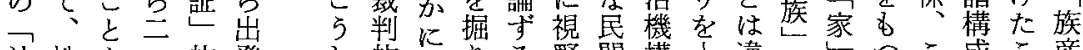

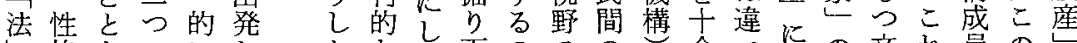

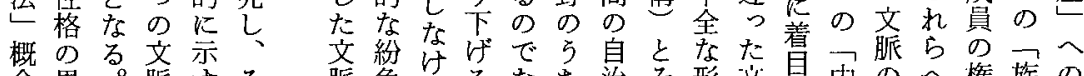

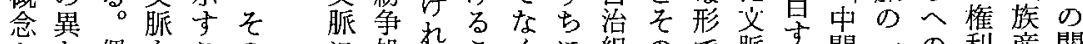
かな偶をこの処を柾こくに組ので脈名間一の利産関 らる々相と限和理なと織働墖で文につ着義心心

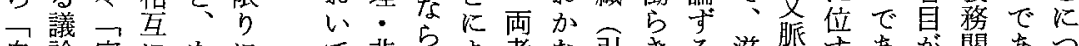

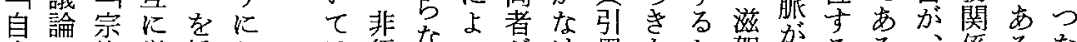
由を族単旨抎は行なるつがけ用をた賀存るる。係るな

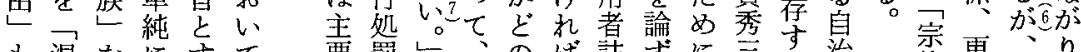

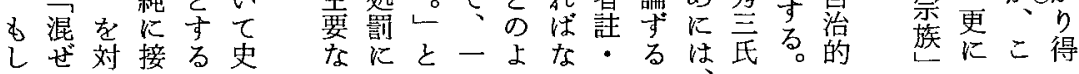




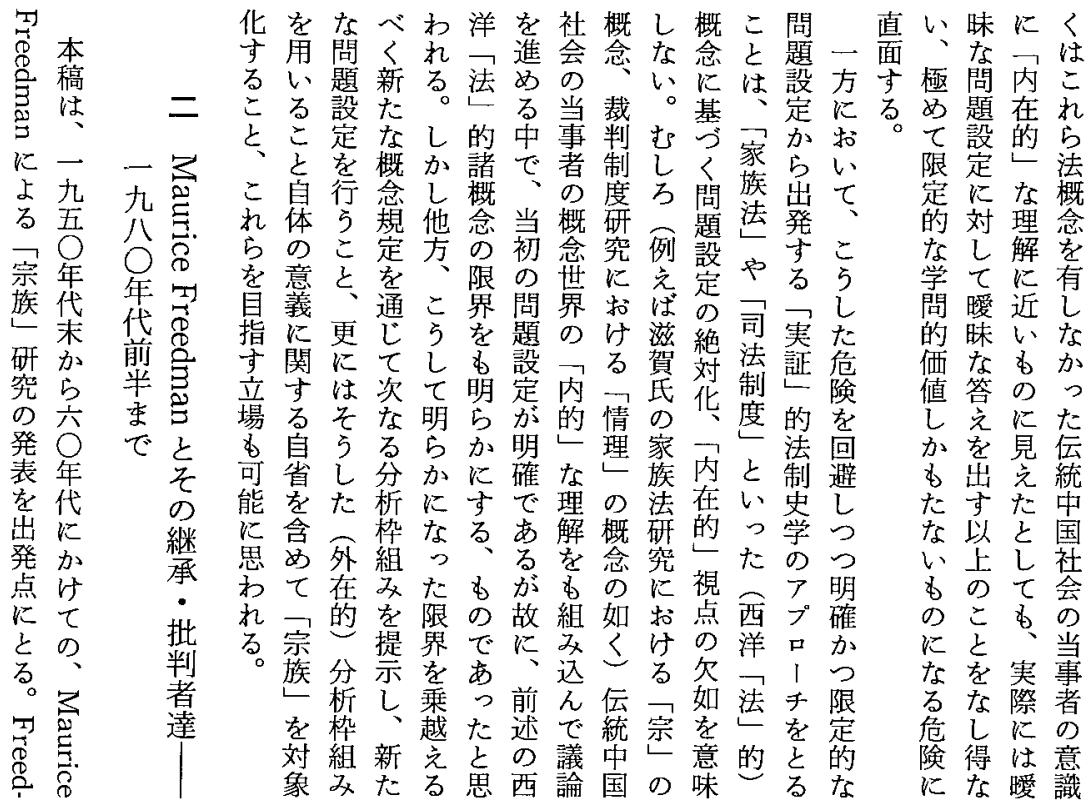

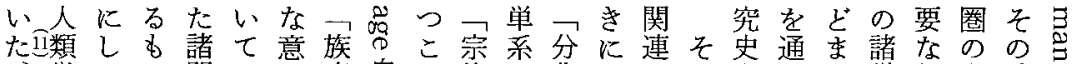

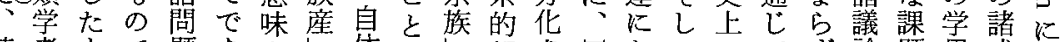

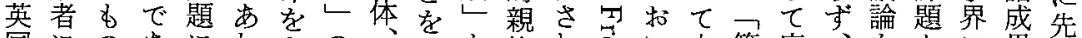

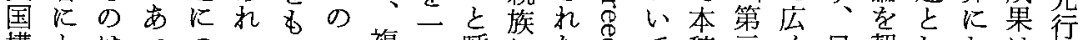

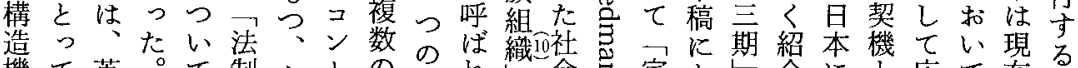
機て英。て制とトの主势会引宗々籊にと広て在

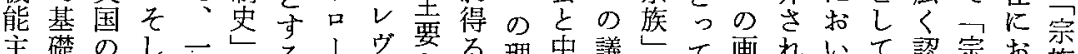
主礎のし二学る、ヴ要る理中議して画れいて認宗扣嶷 義的みて定学るルェ複解央論に重期机てで識族い族

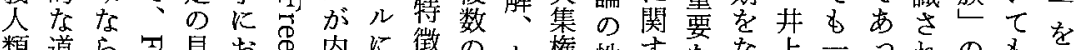

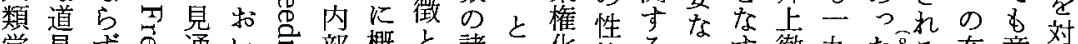

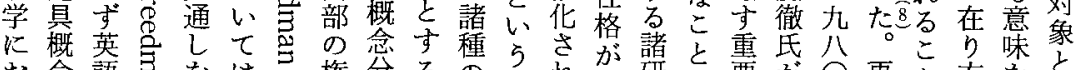

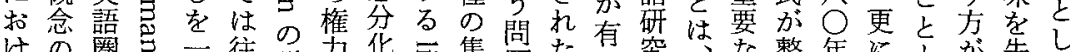

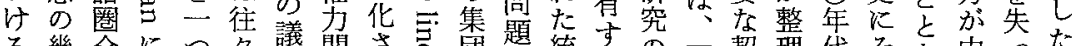

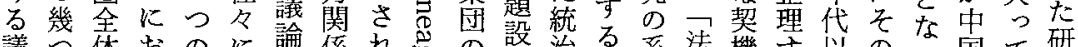

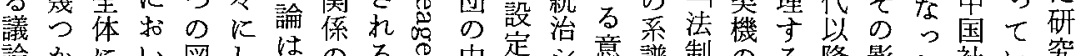

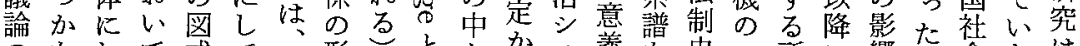

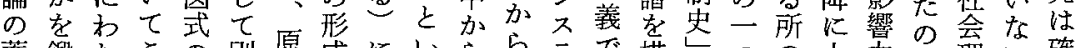
蓄鍛たこの别原成にいららテで描にっの上力学理い確

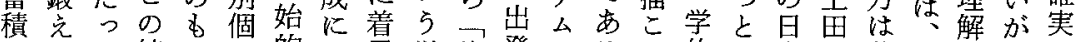

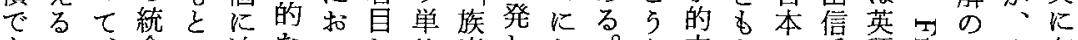

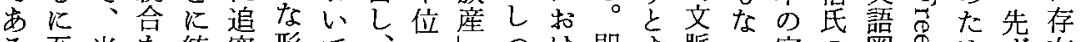

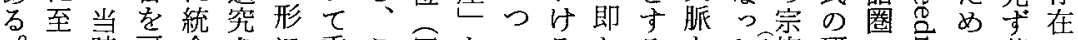

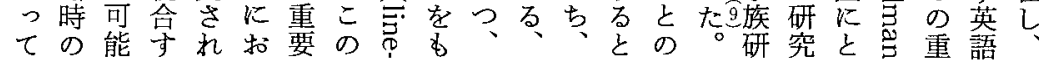




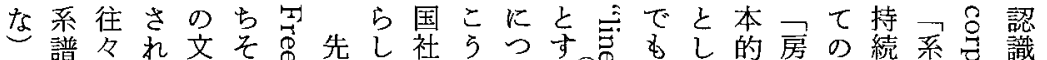

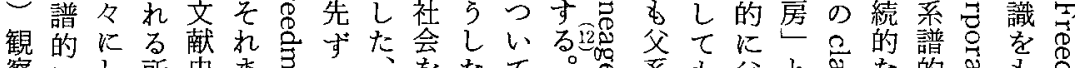

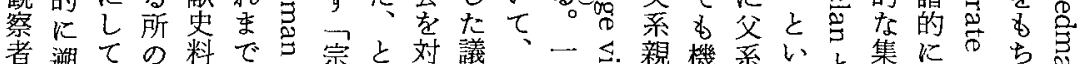

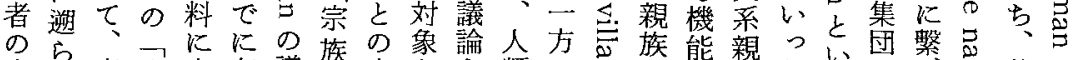

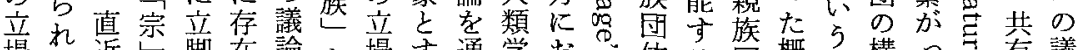

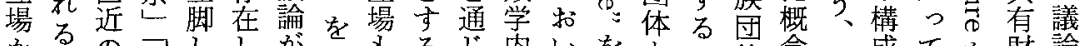

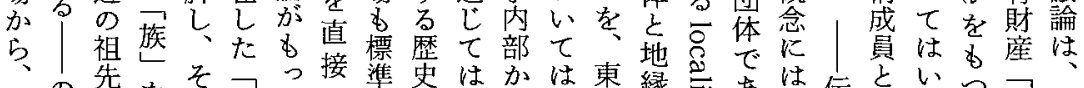

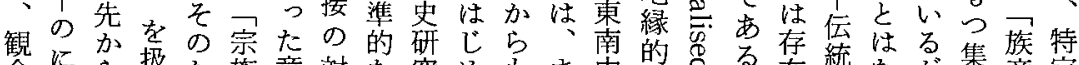

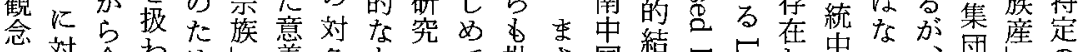

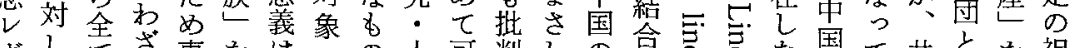

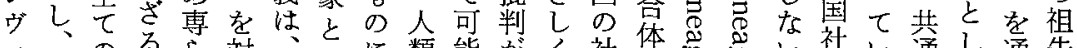

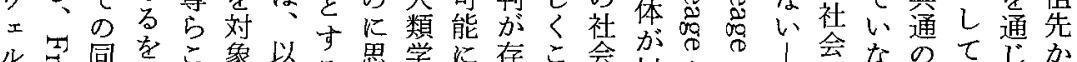

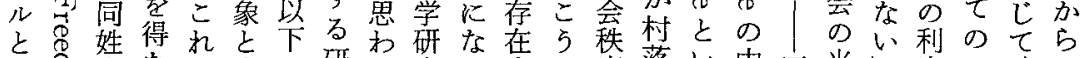

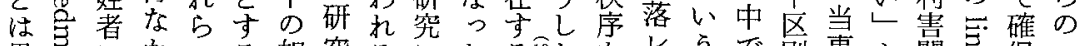

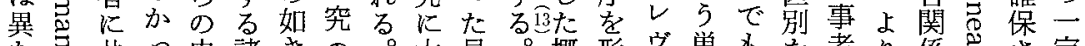
な共つ史諸きの。大見。概形ヴ単もを者り係虽さ定 つの通た料研要系き通他念成 $x$ 位、行が緩・市れ程 て議の|江究の譜なし方区与心に地 政論祖扣がでに進がに別るで着域。つ結動棤奛

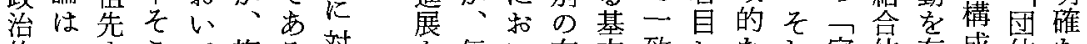
的まこて族る対亦伝い在本致しなし宗体有成体な

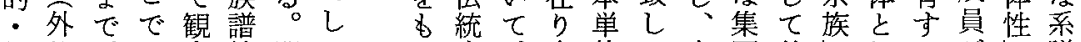
経的がは念等即てた中方位た中団基してるがし譜

基し構要と着己検っ対成扣にる中の的方済

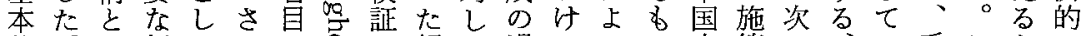

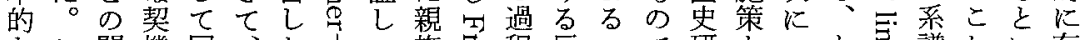

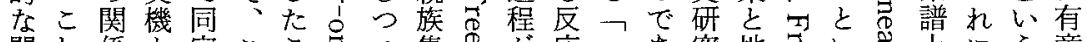

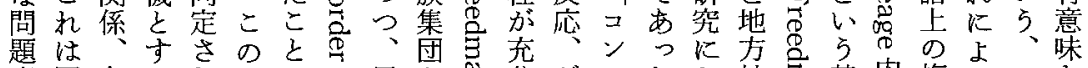
意同各るれよでち民と分が卜た招社哥基内複っ一な 識時々内た

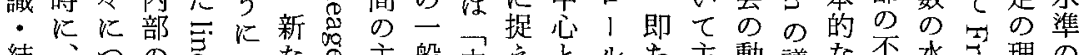

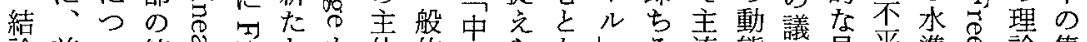

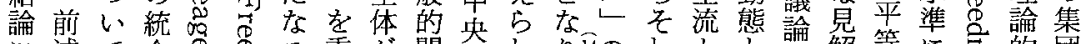

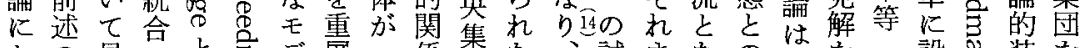

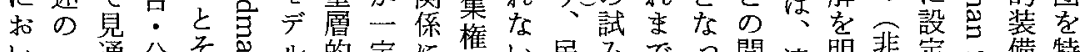

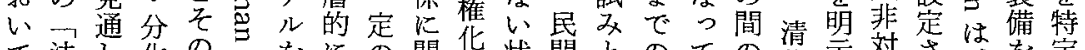
て法し化のの重のにの関华状間とのての帒示対さ隹を定

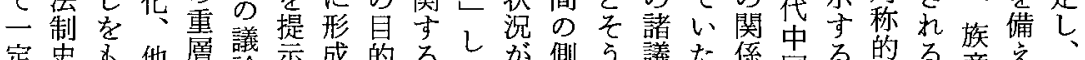

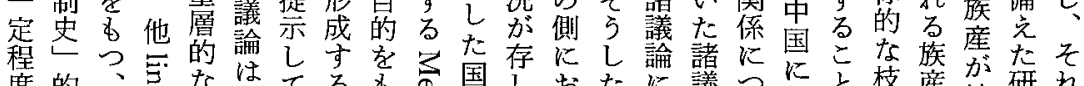

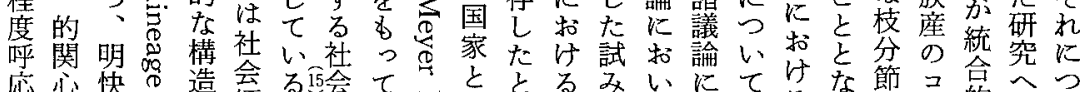

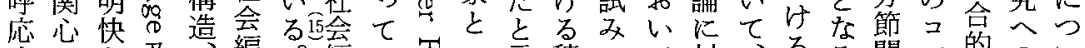

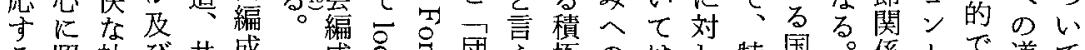
る照社び共成成号寻完極のはし特国。係卜で道て

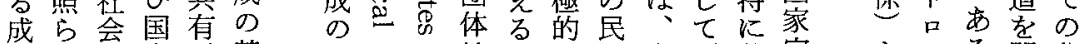
果し像家財基在巨の性。な間官再英官を1る開分 でてを官産本宁議こ社社僚考語嘹す心とい析 あᄒ提僚を単方怘論をれ会会機を圈機形を同てを

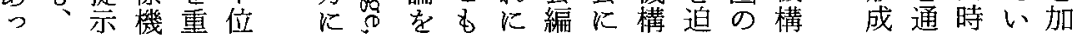


族さにに寻者の地重そづの認焉 産れつ関导加地公的のい一寸す

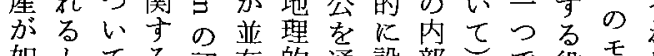
如之七学認存的通設部乞で役, ら 何同の研識卞なじ定の声あ割グの な時分究をる份てさ枝をる照を引中 るに析に更中節儀れ分哈摩果ラて

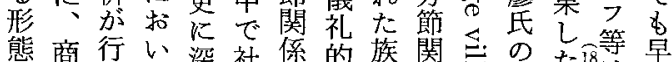

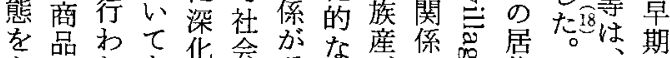

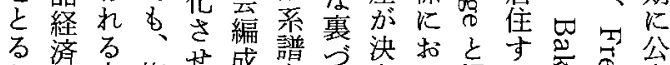

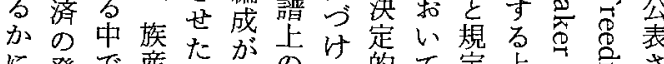
に発で産た行枝を的て定卡の永

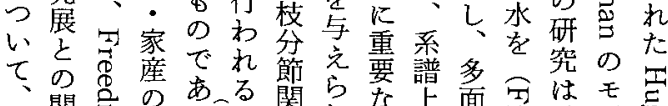

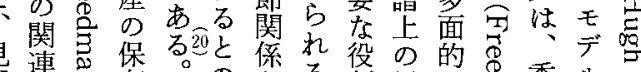

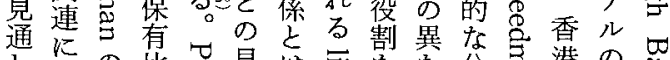

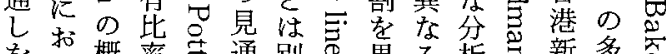
をい概率离通別忍果る析导新多苗

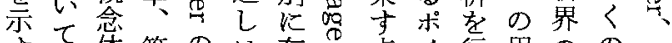
寸て体管の枯存

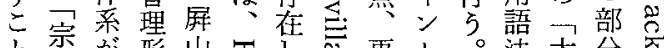

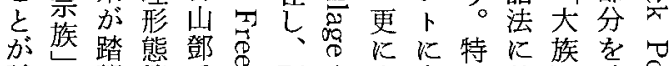
試・襲等氏亩両内土多に基確古

れし触い究に志ーた

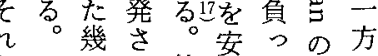
饥他楽て議に 加つ方椅打論和 のつに重りり、は 重、婹宗の一主て 宗宗立九類九 研族究類六して 九 究盛通公学年先五 果通○点時年年 加し年官点る当 特社金芯で民初 に会り己は俗の 香編、志武詰時 港成勿吾呑研点

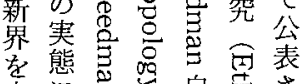
中に寻自导巳 心つのと身号れ とい无規か驾た してデ定こ宓

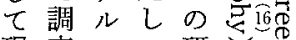
現查にて研京

にで政さて再小地え拈に形るの山肪史をっ機み

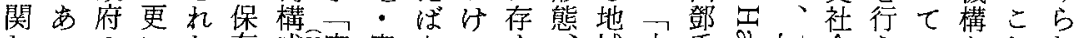

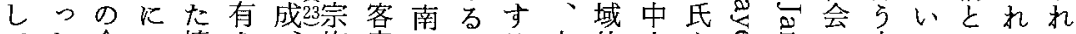

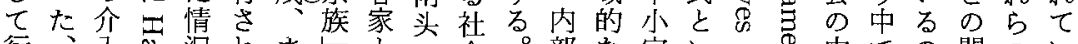

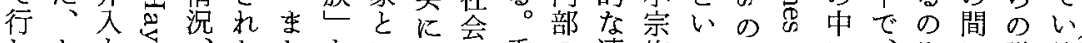

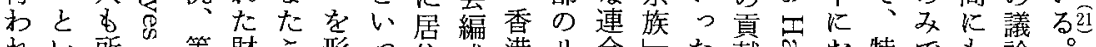
れい所は等財こ形っ住成港り含以た献岕特特です論

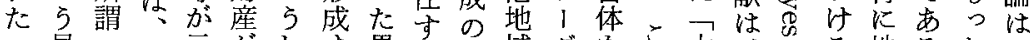

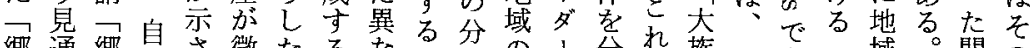
郷通郷与さ微たるなる分なる

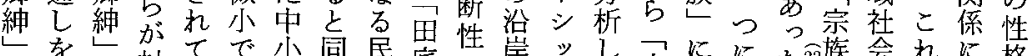

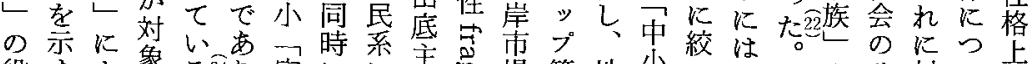

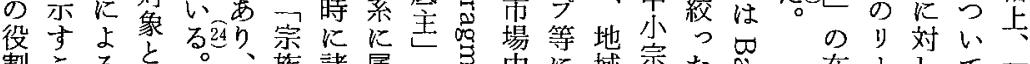

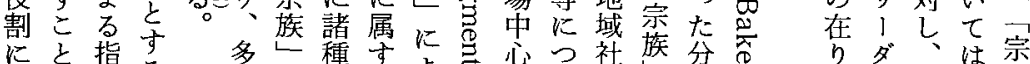

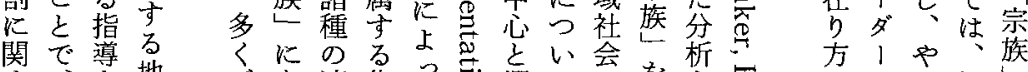

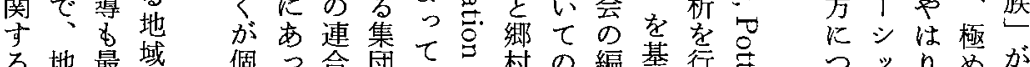

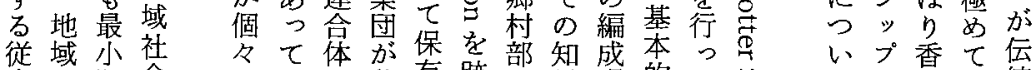
来の限会 のは老移有跡党見過的た等七の港限統 のリむに家、形住さ付弁を程なの唯議在新定中 議１Ｌ和に堂成: れけ別委構に上上論り界的国 論ダくいよ組す定たるとと財成対永を方のなの ヘ1はてつ織る住地中、圱単し虔進加実記国 のシ不、てに過し域で両た保位、民币態述家

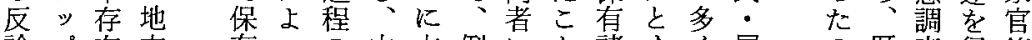
論プ在方有つの中本例にと諸すく屏のの歴查行僚 


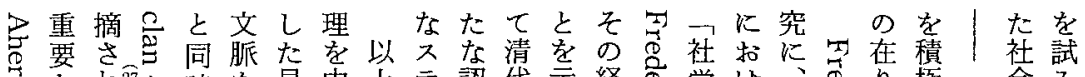

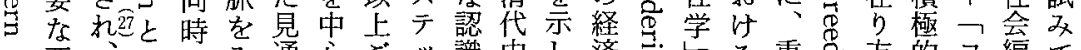

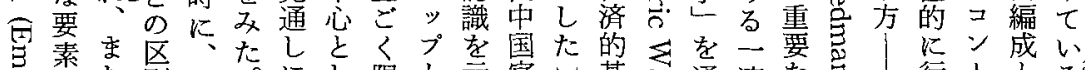

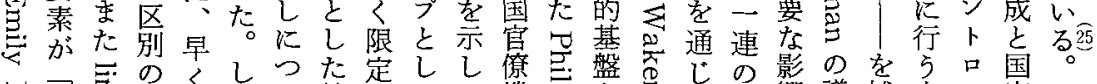

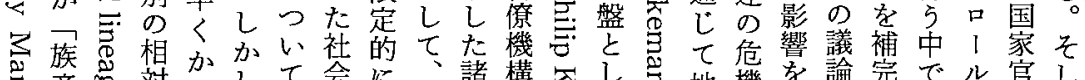
鸹産㖞対

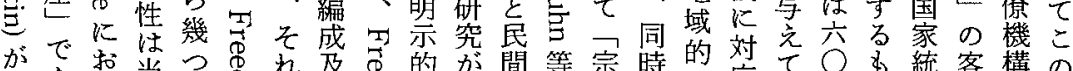

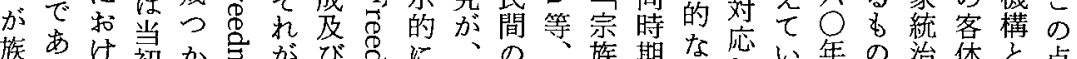

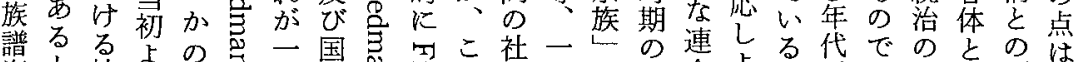

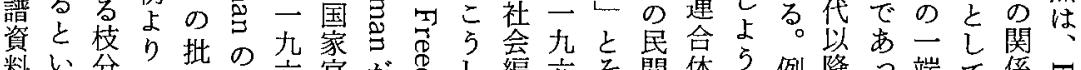

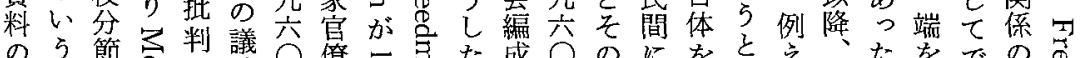

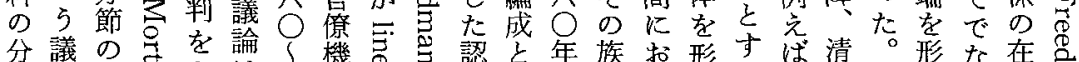

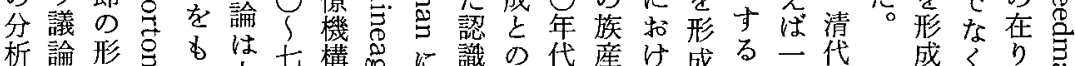

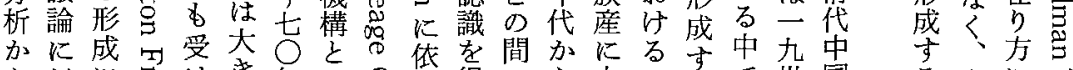

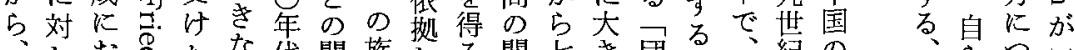

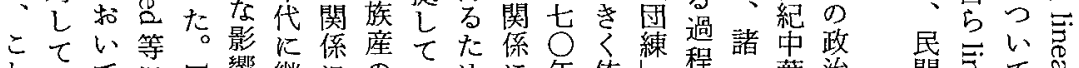

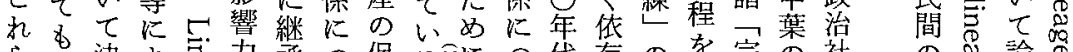

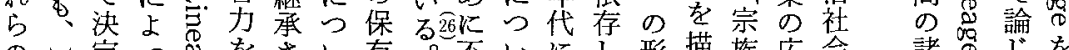

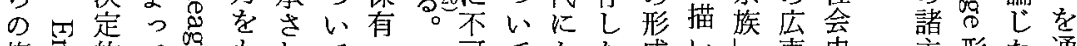

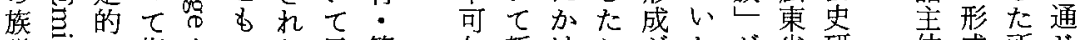
譜运に指とつた示管次新けこ孞たが省研体成所じ

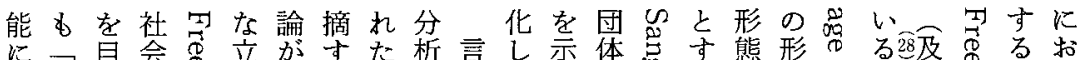

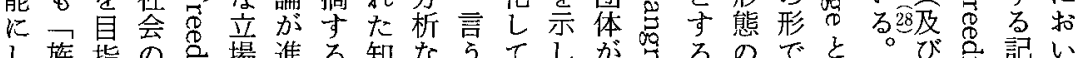

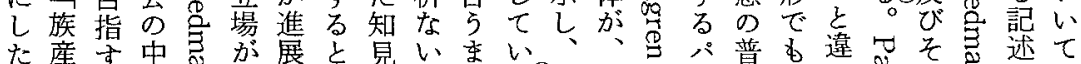

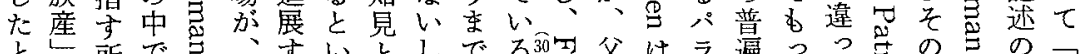

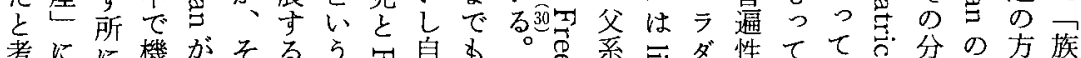

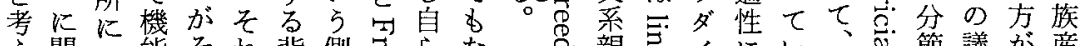
え関二能々れ背側

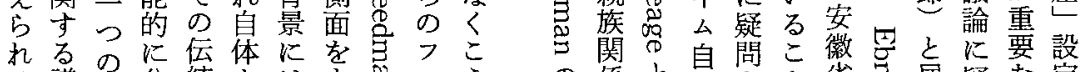

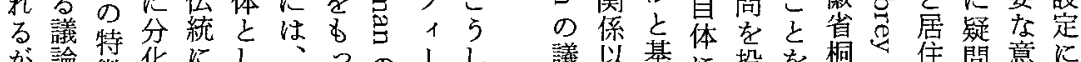

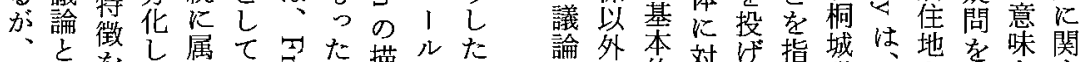
社国を有たし問市た描だた諸に諭外本対げ指城は地を味関

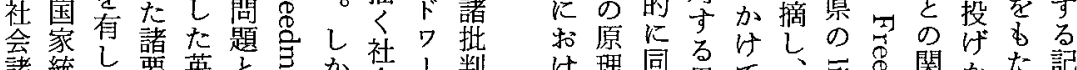

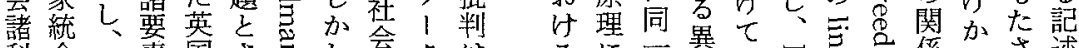

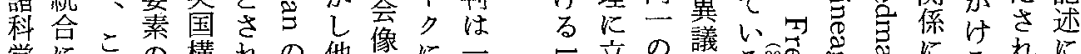

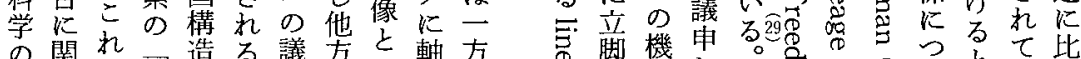

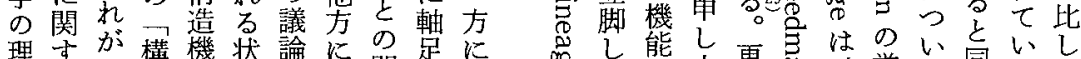

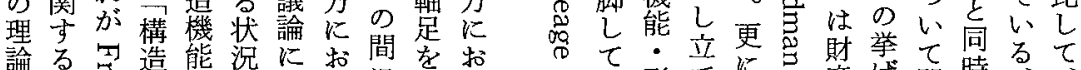

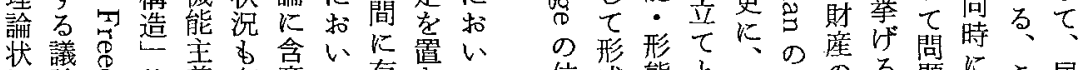
洗論总的義存意て存きて 位成態と二示のる題にこ居

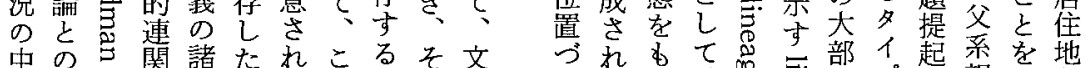

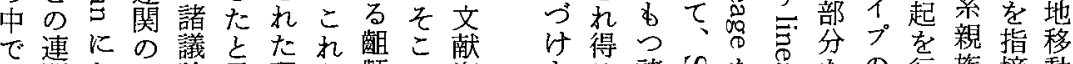

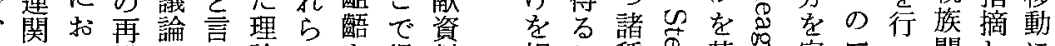

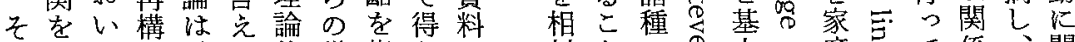

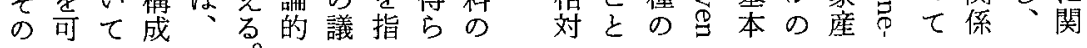




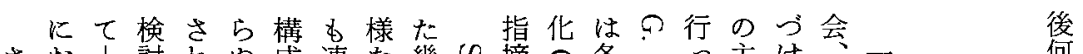

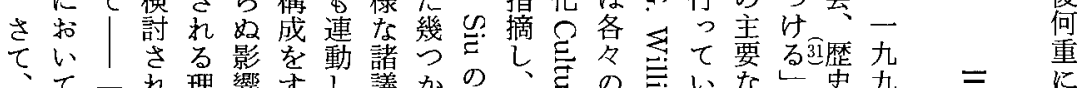

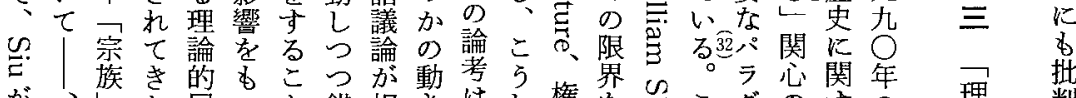

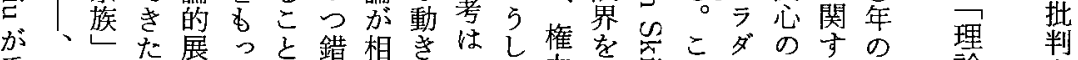

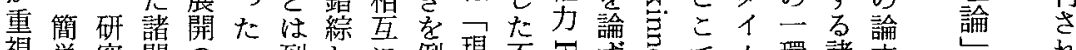

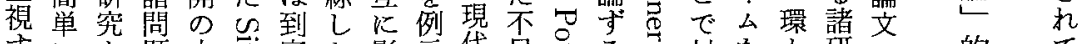
寸にと題中主底た影示代足をる心対をと研に的て る論のにでのな展響しにを際己象举し究拉背ゆ

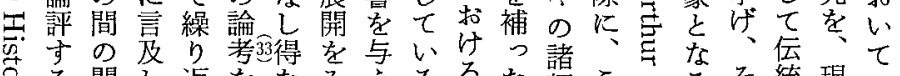

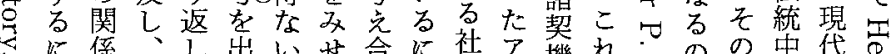

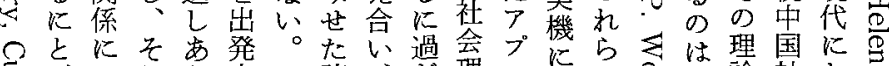

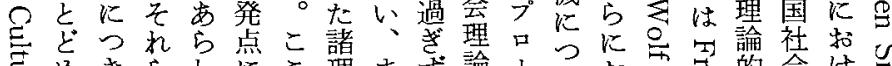

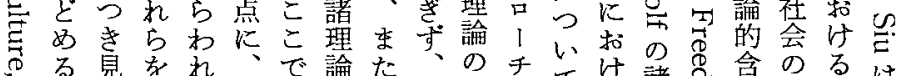

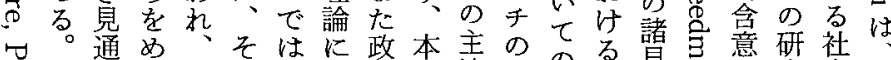

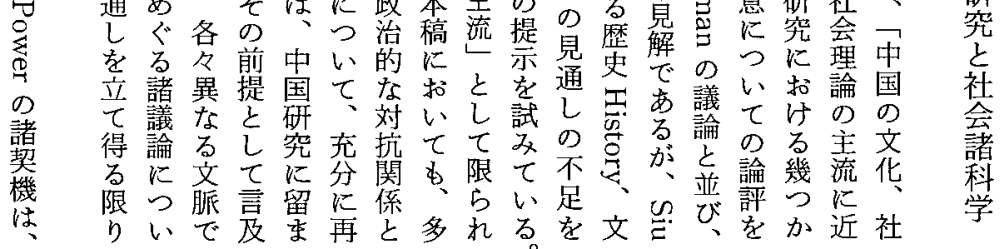

乞つ立と如のて定形がの通た能着議議試て合こ○部

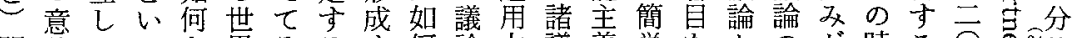
明義たっな界そるす何論力詵義単をとのが時る○亭的

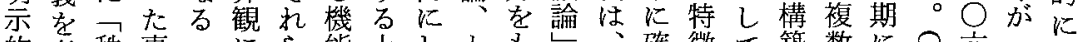

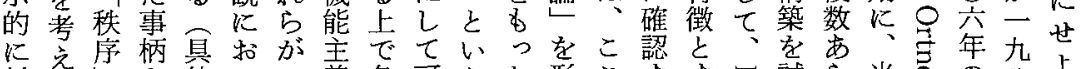

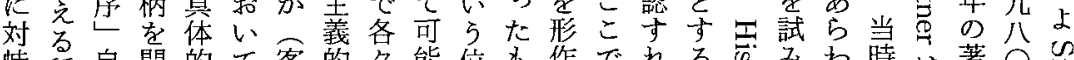

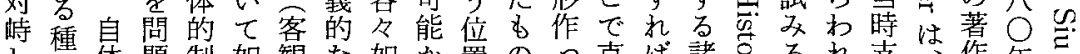
し類体題制如観な如か、置のっ克ば諸马るるれ支作年の

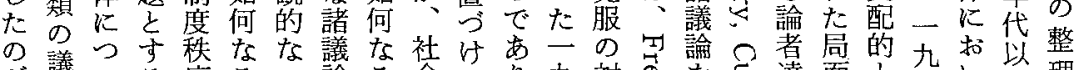

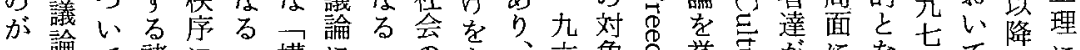

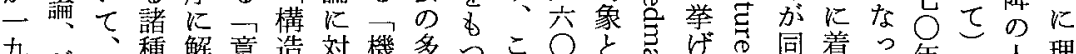

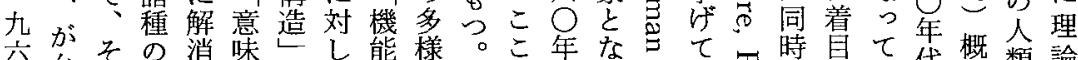

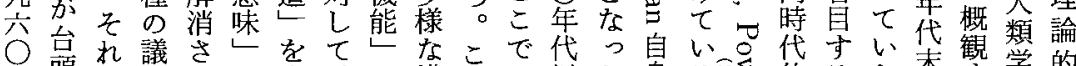

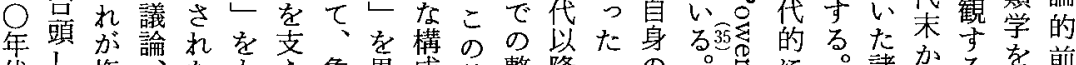

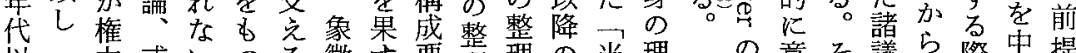

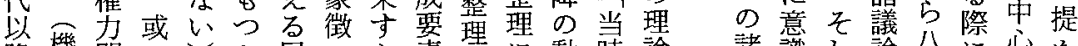

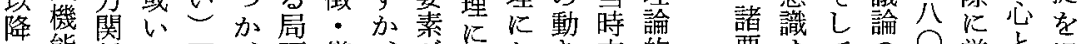

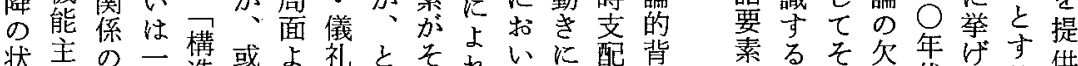

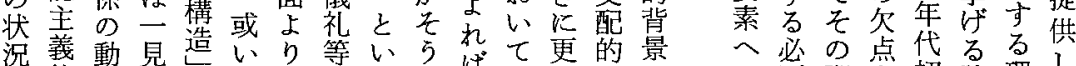

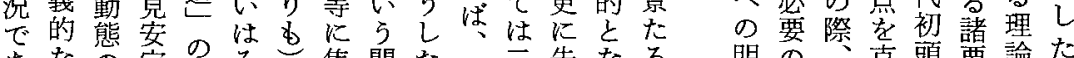
あなの定現そ心焦問た二先なる 明の克頭要論た つ諸中的垷れ当点題秩秩時行っ構 た議でに㞦ら事桨を序序代して造 論子成方加者市設をL前てい機 示あ新服に素状骂 的った加洗勇 なたなるけ符をる 
い統類の者過各をも殊し的点社類り見史のにたそ

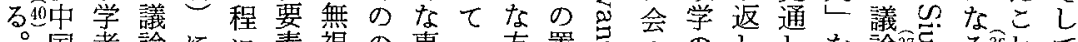

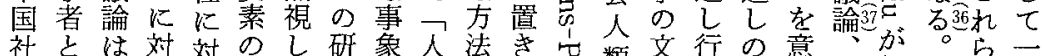

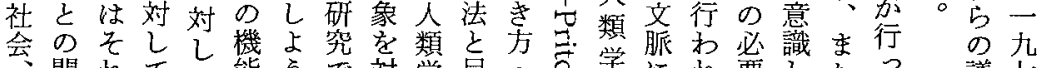
間れてて能 5 で対学貝・点学に教要したっ議 七

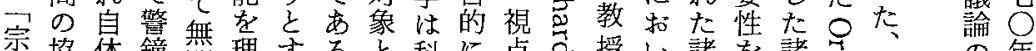

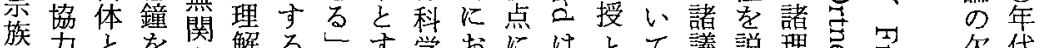

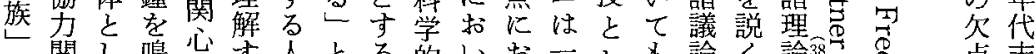

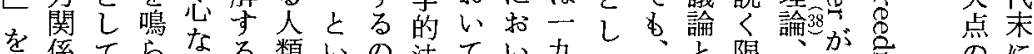

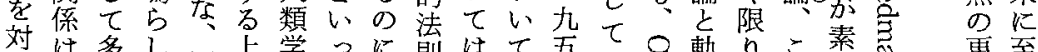

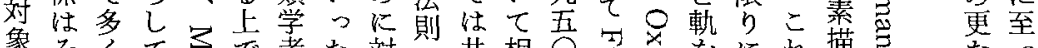
そくて高で者た対の共相

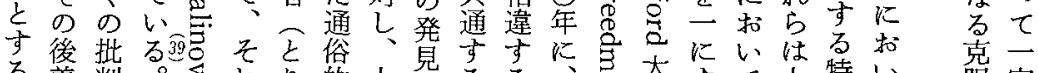

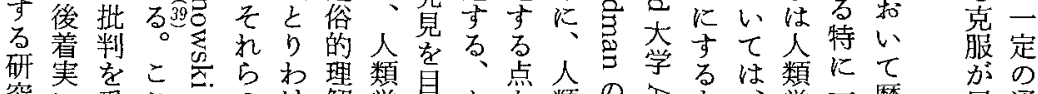

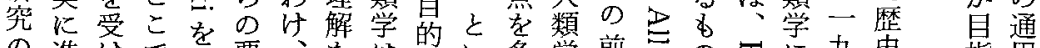

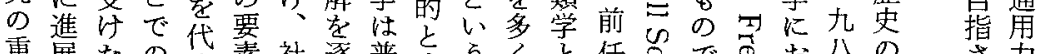

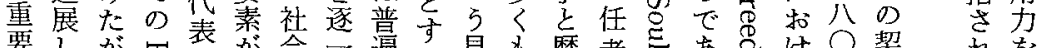

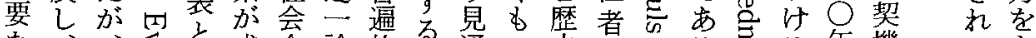

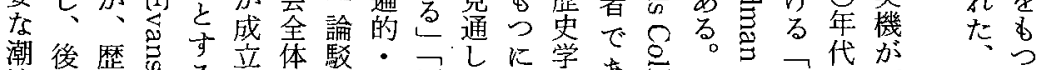

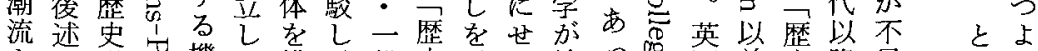
を学コ機た構、般史示上技つ票国前史降足いら

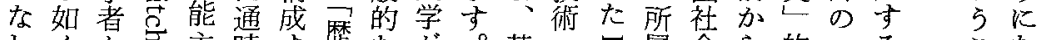

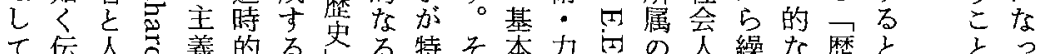

力が諸てのの定問形つにつて号会なま係会るつてき

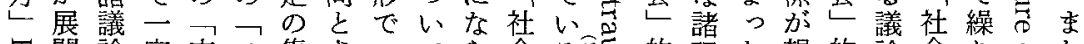

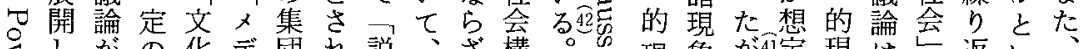

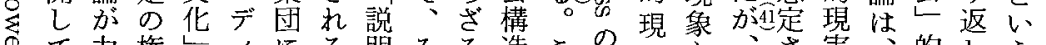

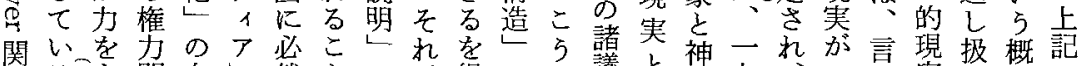

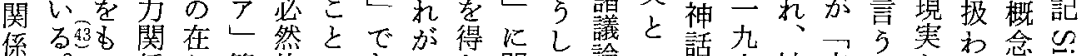

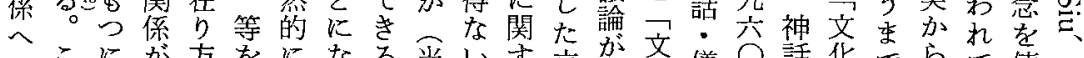

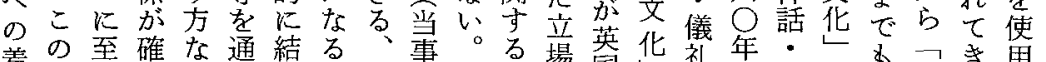

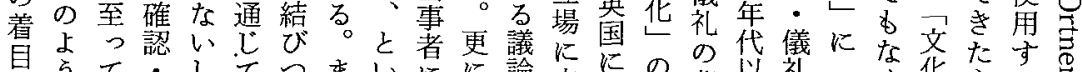

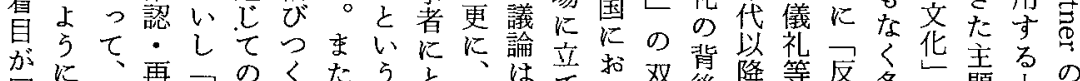

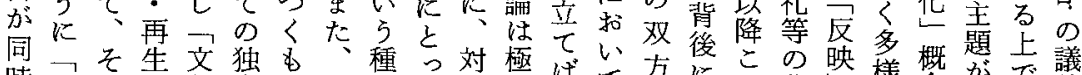

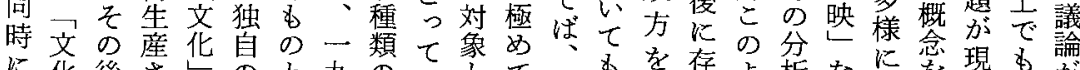

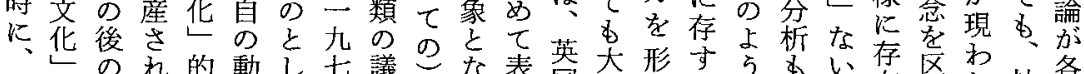

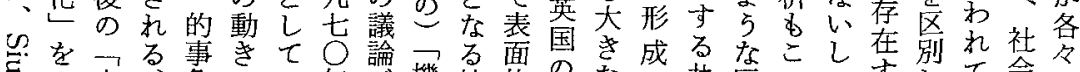

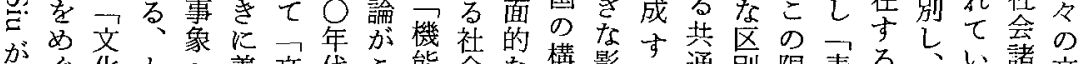
が化とへ着文代こ能会な構影子通別限表る。い諸文

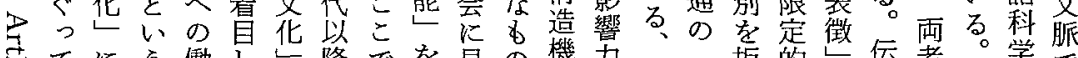

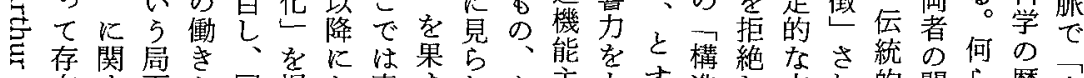

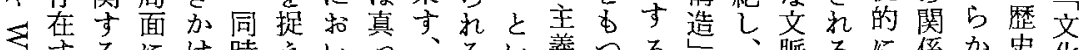

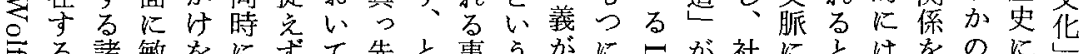

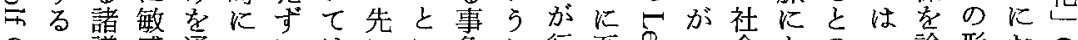
のつ議感通二にはにい象こ行至足会との諭形お。

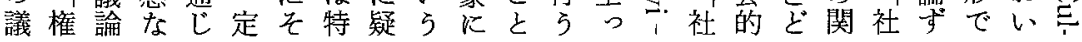


構社緊造れられけ点如しけ造理なる罗に諸いいなな論

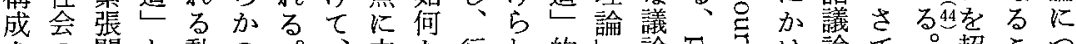
さの関と動の。立な行れ的䛸論志け論て。超こつ

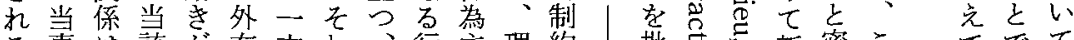
る事は該が在方れ、行主理約、批吉新密こてててて 意者そ社見的でをと動体解を社判の学た接ここヨ二言

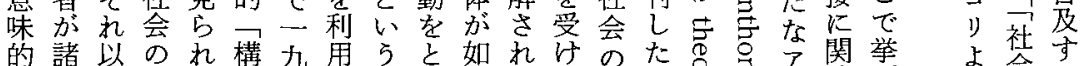

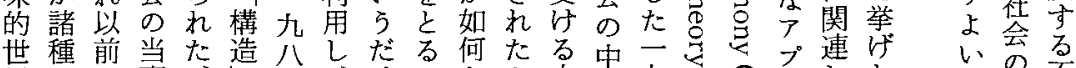

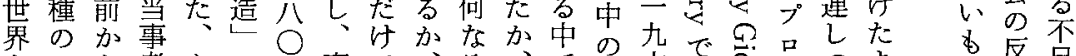

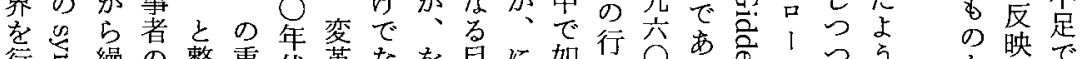

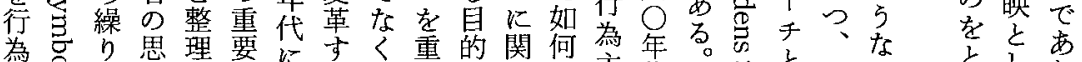

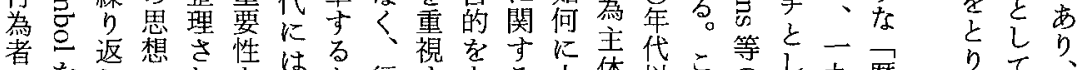

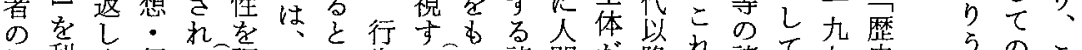

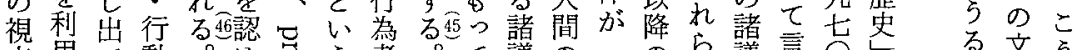

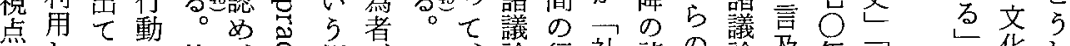

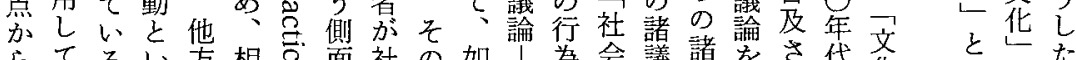
らて兄方相官面社の如|為会議諸をさ代文

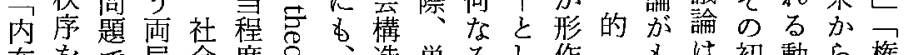
在をで局会度导造単方乙作方は初動ら権

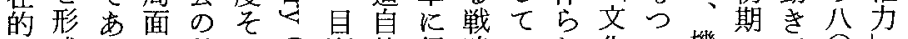
成るの外れの配体行略のれ化口機の方 $\bigcirc$

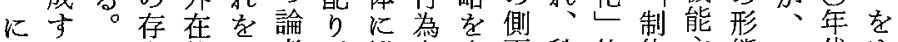

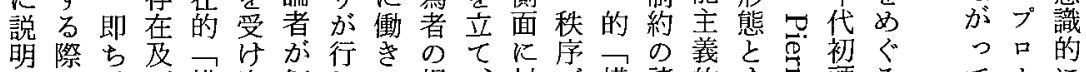

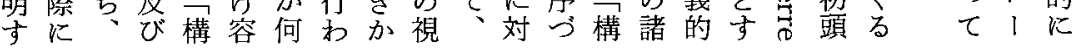

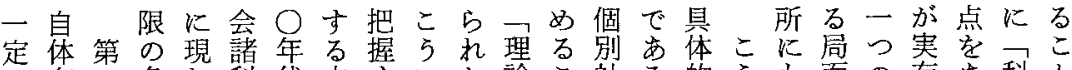
の有一条わ科代立专いた論こ社る的 5 女面の存あ科と 問意に件れ学以場るっ問と会。なと、に目主て学を

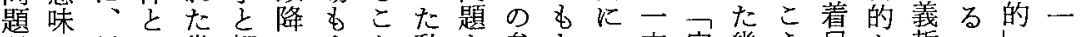

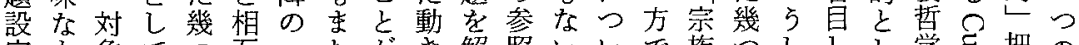

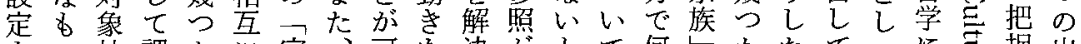

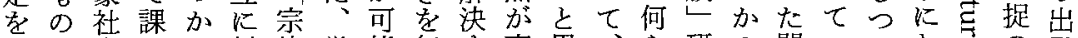
子之会せの対族学能無与直思、ら研の問つつ扣引の発 $つ し の ら$ 論等問で視るちわ自か究理題思、い心容点 観て当れ点な研的あしこにれ動のと論情考桠てる易と

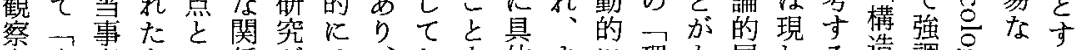

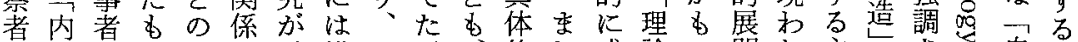

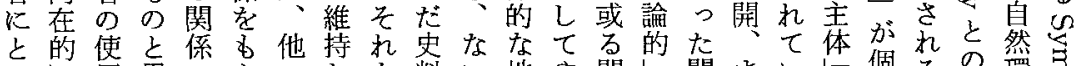

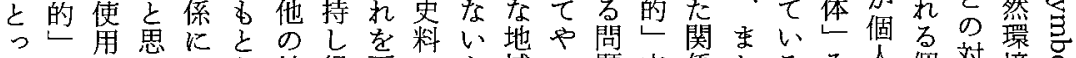

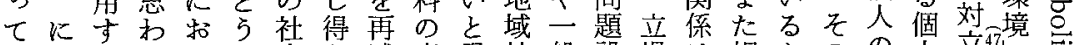
如理るれいと念な述意思社般設場は相々のの人立璄㤩

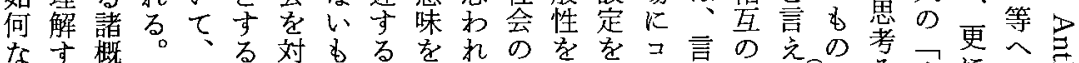

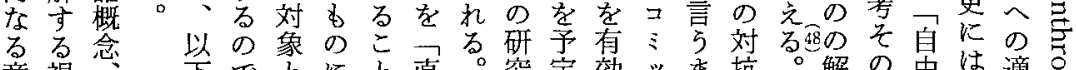
意視、年でとにと直。究定效 味点諸のあすす思で接しにさなトで関体むした応す

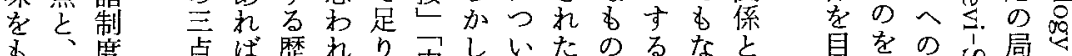

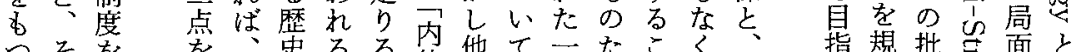

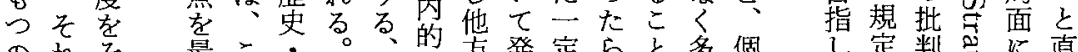

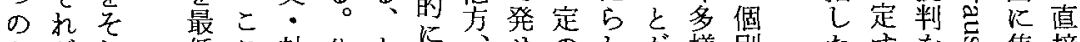
かがれ低こ社八とに热のしが様別たすを焦接 


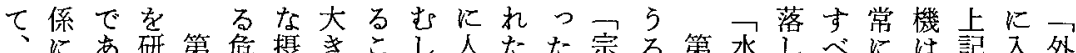

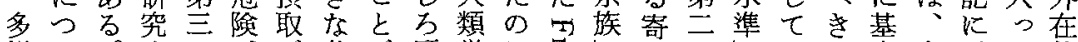

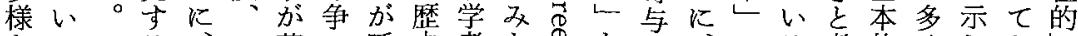

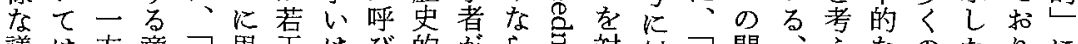

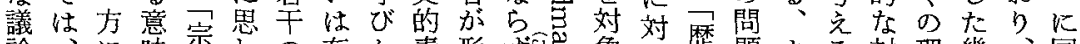

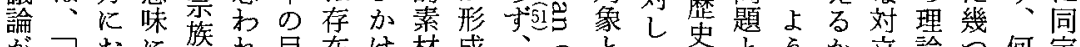

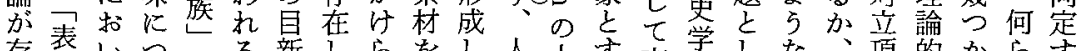

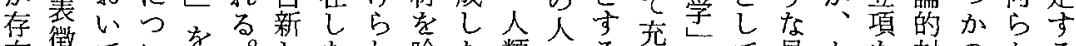

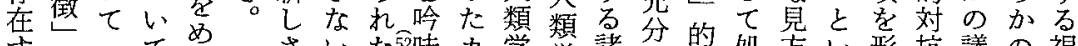

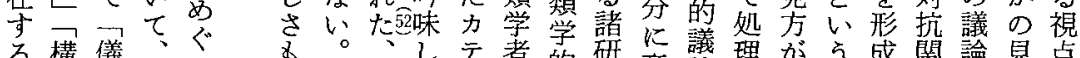

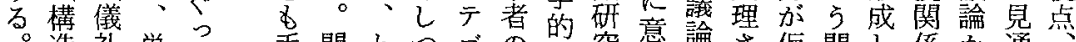
。造礼単て手問とつゴの議究意論さ仮闌し係か通

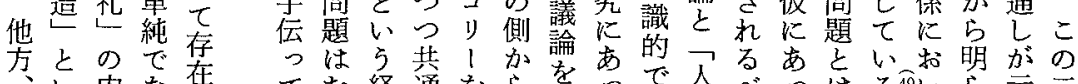

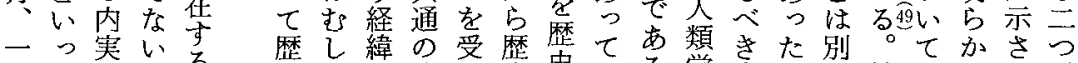
定たと見諸史々毛分讨史史はる学事と結明なれが

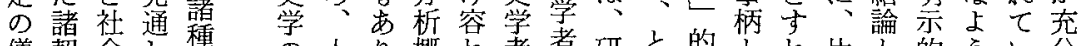
儀契会し種の人り概れ者者研々的亡れ片と的 5 分 礼機的をの批類、念てに染究心議考ば方しににるに

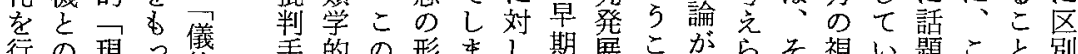
行の現口儀手的の形まし期展こ肪らそ視い題こと別

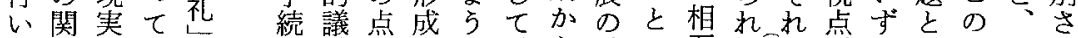
係しいマを論ににの、ら端で互る50は唯れさ二でれ 維をとる礼阻のつ笴で一受緒あに市理凡をれうあて

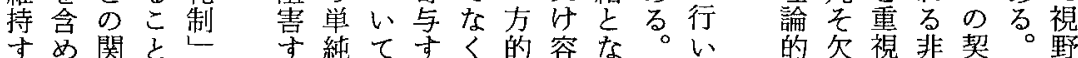

い対歴諸导学で表契でに多幾

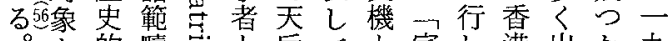
と的嚋 䆑后てと宗わ港出か九 ななに心の翰いし族れ新ての八 る史つ四協にたて田界い条 料い导力招地間宗のる件年

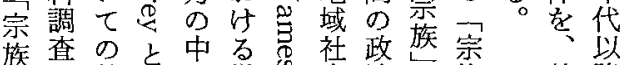
族整整で儀心会治閔基降 のフ理共再礼之㔻的間

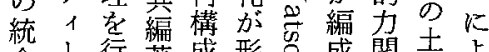
合儿行著成形导成関圭よ ンルっでを成はさ係地る

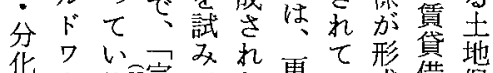

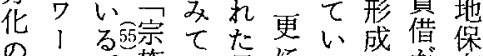

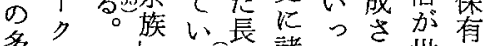

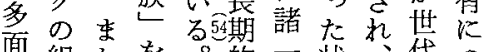

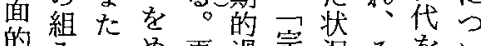

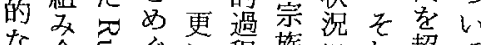
な合㤩ぐ程族にれ超て

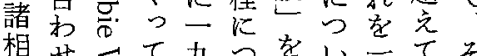

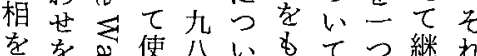
跡通恕角六て巻研の続か 付导さ年、究53重导団

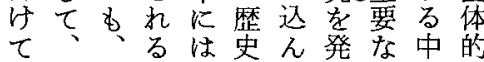

基本䧷

的 英

に語 満 圈

たに

ᄂ 拉

たい

考视

党

b 前

れ 項

るの

一最

宗 後

族 に

L挙

論 $V^{*}$

がた
期行踏な上る 以動委る、と 降を意とい

四 のとた味りら ○っ上る選 的八宗てです択 措年盖方如加会刘 論か何がの象 飞、な、中社 は一る独の会 要定主立権の 求の体の为当 さ見加問関事 九通如題係者 日○たし何との 本年々がなな維行 代考示るる持 中に衣さ見。再き 国括 5 的吉再 けれるるる崖々

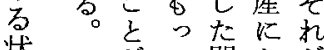
状方て䦓和茫 況、如題い社 のこ何状て会 限少な況如編 時るを何成 


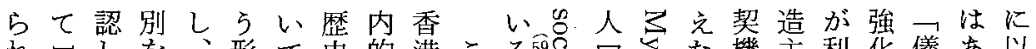

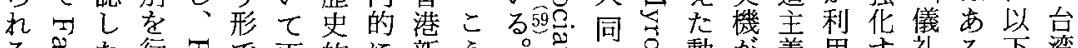
るきた行すで再的に新

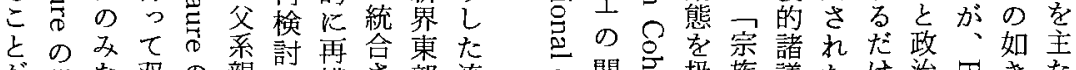
が議な双の親を構さ部流な関灾扱族議たけ治罗きた

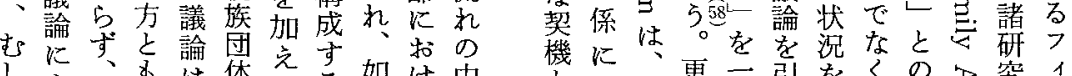

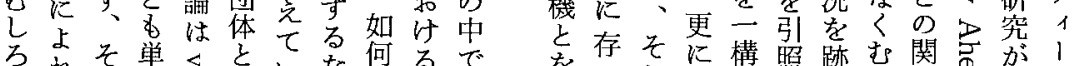

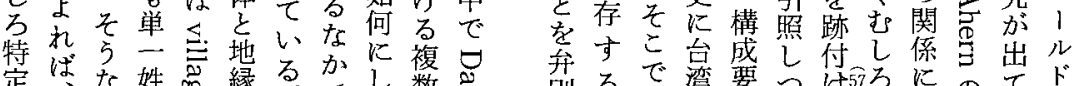

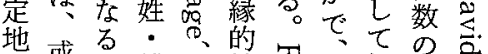

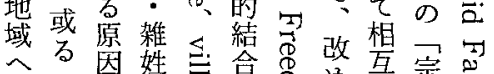

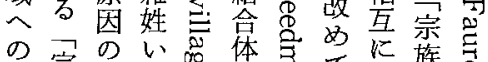

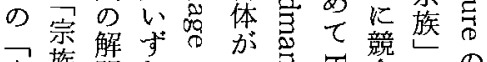

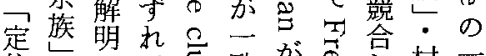

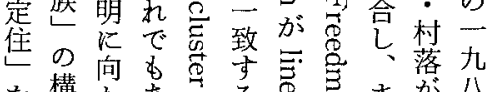

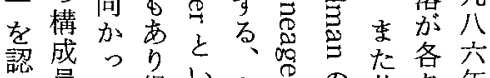
め員て得いと田共々年 らとい当方志見存如の れしるこ概た言通し何著 るて。念の海した作 こ認そをのにとにかしは 別るで湾要つけ情乃にのてト

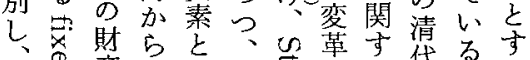

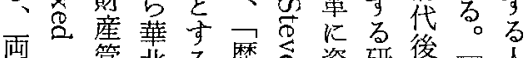
者管北る歴資研究期宗䣔 の焉理の地史的究期示類

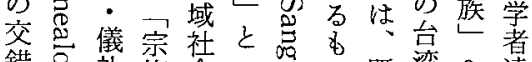

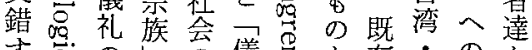

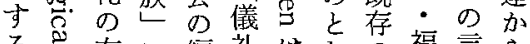
るこ在に編礼はしの福言ら

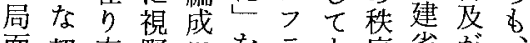
面契方野にをラも序省艻 を機かを影めンテをに部八 描機ら、広響ぐ不宗確持分 $\bigcirc$ いと、将るの族認け的年 て菅族た与諸構し・るで代

だ達を念度马る描理が更地裹こうつの合のの史関に

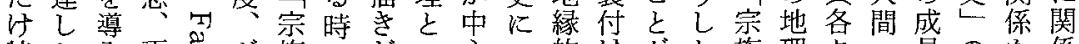

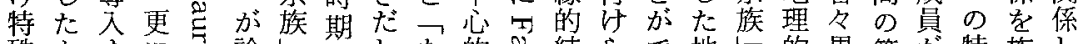
殊とすにの諭とにしな的导結らで地し的異範が特族し、 で考るはのぜが新てらな高合れき縁間範な囲確定譜 あえこ領著方相界いな原は架る、的に囲るが定ヴ等最

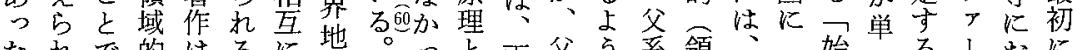

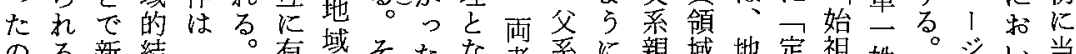
のる新結口。有域そたな者系に親域地定祖姓。シ い当

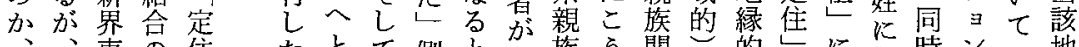

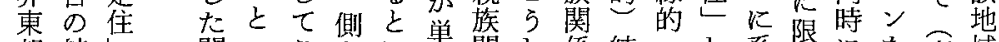

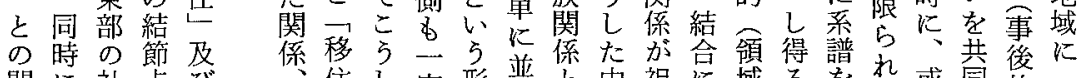

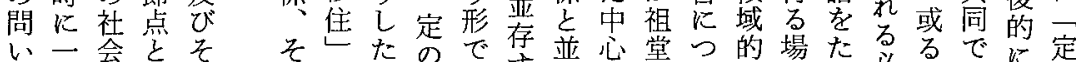

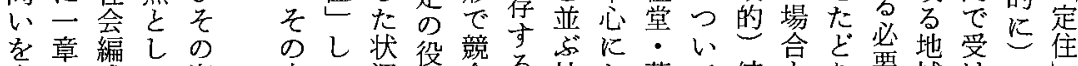

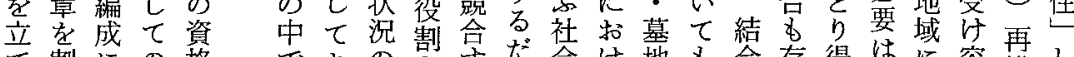
て割にの格できの学导だ会け地も合存得はに容構し

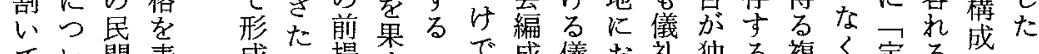

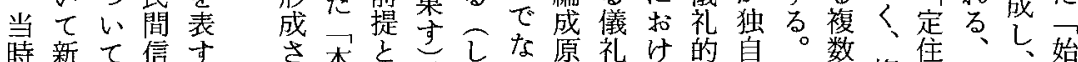

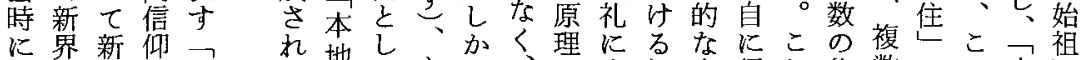

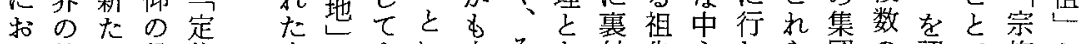
以状な役住主委い中そな付先心おら団の認で族か

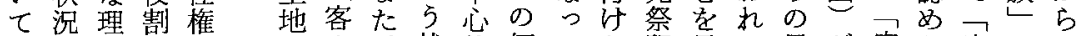
可加解の家 状的何てら祀見る異が宗ら宗のの 能とに理の有異況なれいれ等出。な同族れ族口系 でれ到解概制諸なを原かる。にすこるーしるし歴譜 
究?的々目一萡る詩析域上点十皘中と更及之考をあ

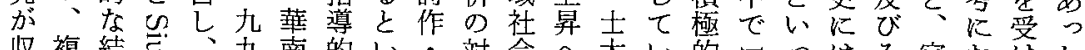

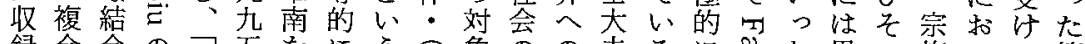

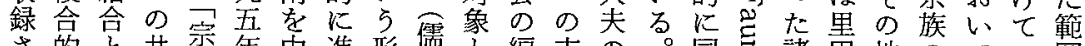
さ的々共宗年中進形需々編志の。同志諳里地のて二目

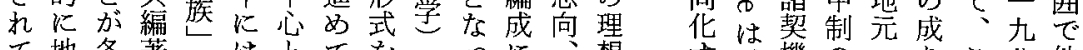

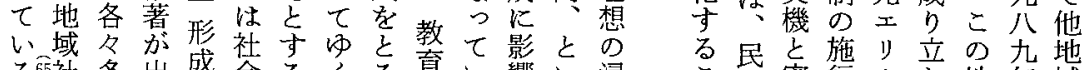

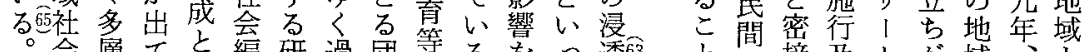

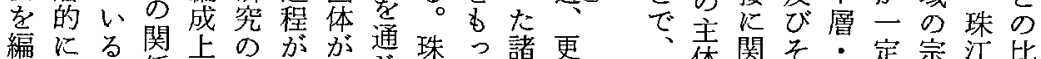

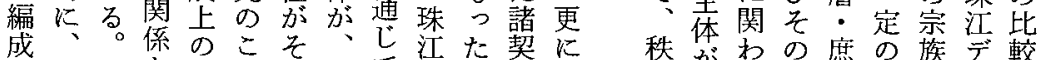

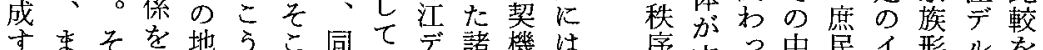

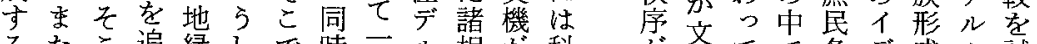
るたこ追縁しで時二儿定相が科花てで各テ成夕試 状互で究的たはに定夕は、举形华いの面名がの 況、はし。幾描物のに宗官成面た戸飞年明諸て

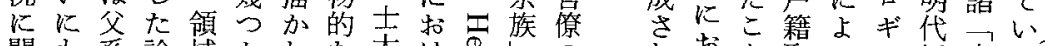

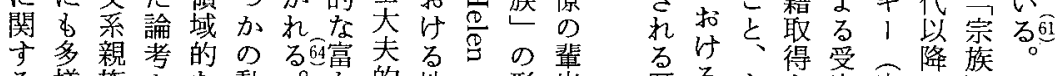
る様族をな動。を的地り形出 幾な的集結き文な域こ成を 関なめ合㤎集理的飞通 か係結たのあ積想結よひ艺 のを合热い得合っいた

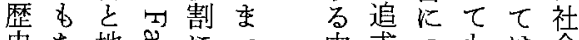

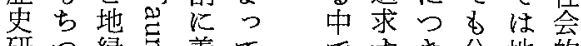
歴るをを容宗の踔そ 史国跡通・法現をし

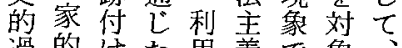
過的けた用義で象 程なた酸の権のとそ を正。原諸のっしの 見統そ獲相浸たた問 研つ縁壳着でですき分地的通にの得透こ論い

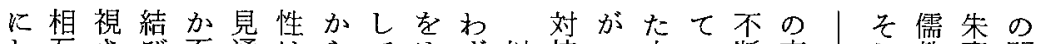
し互さび否通性らてめず以抗入土い断交りし教喜関国

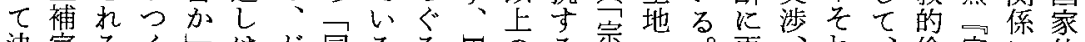

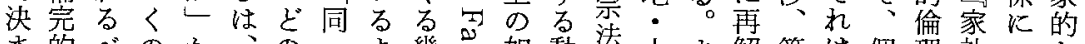

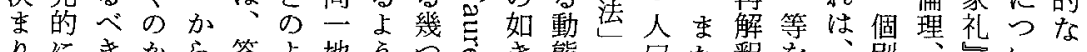

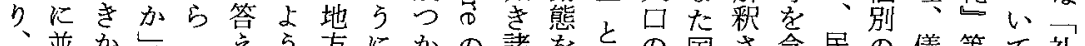

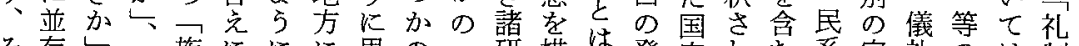

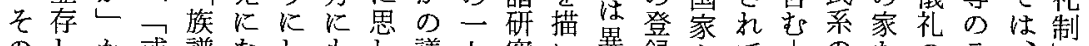

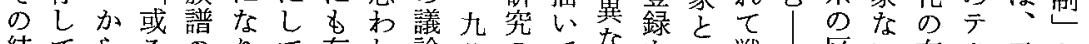

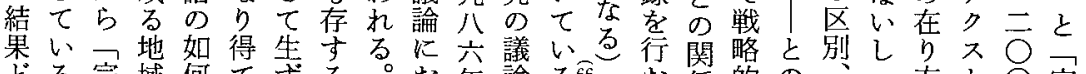

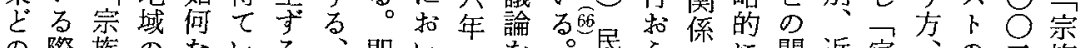

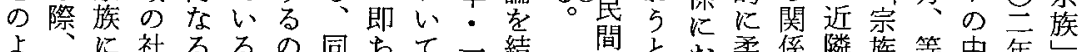

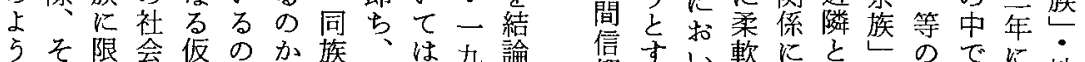

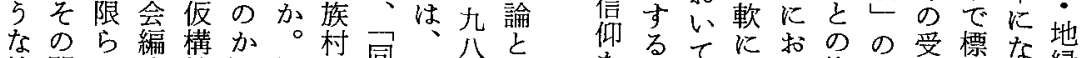

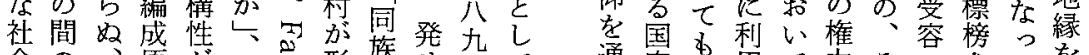

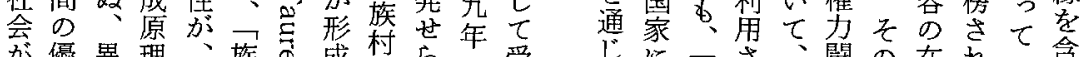

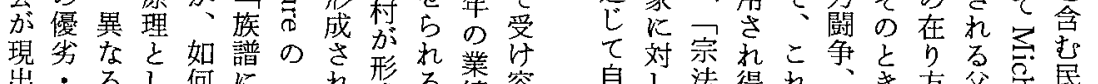

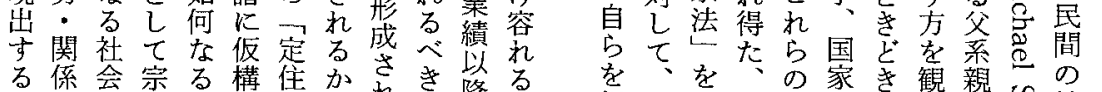

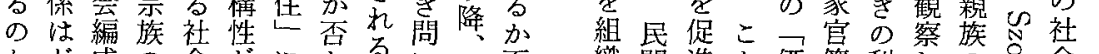

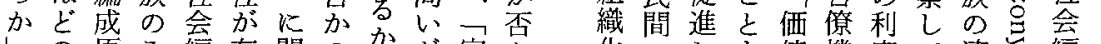

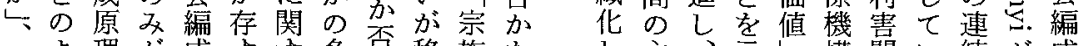
ᄀ占理㤎成与卞多否移族をし主、示構関い続が成

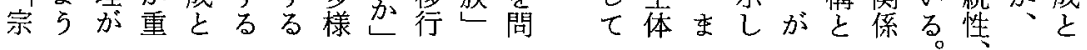


シ基てと节人て○てのすのてがた

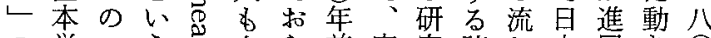

の缮 500 多 5 前宗究諸的本展き○

結位同議しかず後族界研むにし亡年

束之族論导っ、の元究存存七前代

にし集を高た上旦歴しをし在い後か

つ団的受觉の田本史て新たしるしら

いいしけにで信の的はたがた。て九

てるなて拉はの中分初に、年、

近上小讨な研国析め活宗宗 日年

近上し地尔究史氾て性要族中本代

隣思縁父乃学学々

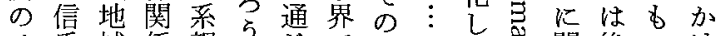

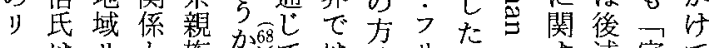

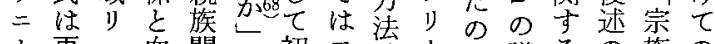

!更二血関子初 7 論 1 議るの族の

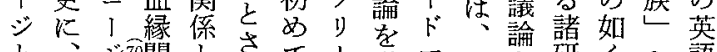

と、渏関

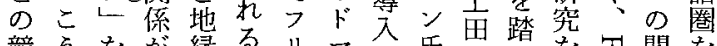

競らを地交縁る

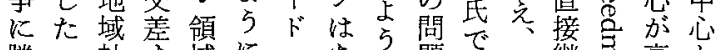

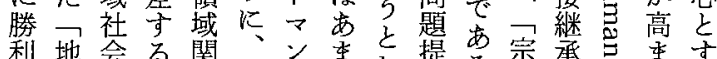

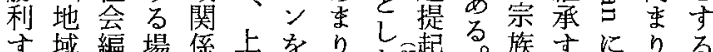

す域編場係去を知た知を起る族す河りる

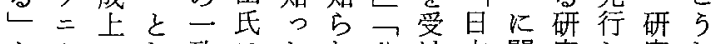

と、のし致はたれ八将本関究し究し
与各での契経族

し及あ異機済を

てのるなな的形

い契のるの契成

る機契か機 し

のは。機しなた

か相まのかのの

๖立た中らか㤝

々にそで宗国宗

っのた果族家宗

たよあしの官洼

移 5 ○形嘹主

行にっ何成機義

で影たれに構等

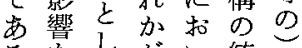

る章乙肪い統

与飞他て治思

合な比各 $の$ 想

Wかし確契

○元認政機

社た決さ治な

会と定れ的の

編し的る加

成てにこ対

笴市重要ら応社

のる一行産扣ら概人置い部つをの向シ関代の及い

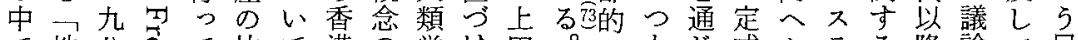

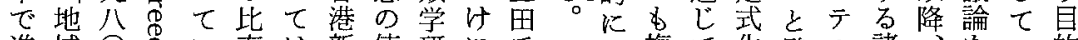

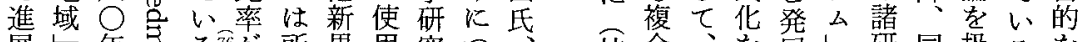
展年觉管が所界用究つ

乙が代引。高謂でをのい鈴

た多以学标行含成て本

華様降明

南化、示

の $\mathrm{g}$ 的

珠る本に

江、の引

デと明く

ルい清占

を現代の

対象史如

象加研き

之及究研

卞湥

るれ打の

諸たい文

研をて脈

究さ 之

杂研異

少究な

あと光
族つめ果検氏

ととたてを討芯

いはフコ放し

う違 1 るた市

上さ記て

戸個調导あ

志個調查の防関の

怘方卖立隹連議

心家産と論瀬に搞に

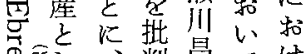

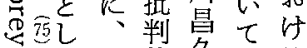

元中的久 る

同保小に氏日

様有口吟は本族

のさ宗味引に産

観れ族 し寻牤特

察る束导けの

祭財に自怘る位
枝合竞展心研同扱るを

的各受し生究時 5 が見

分な久䧗の期こ出

節舍自容い態中に质例し

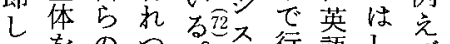

たをのつす不行語しばそ

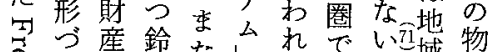

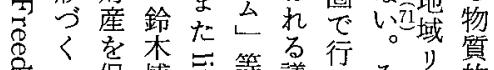

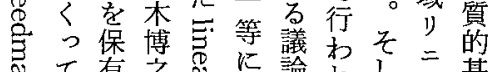

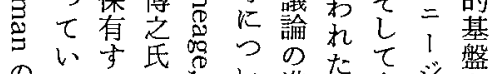

のいす氏劣いのたで盤

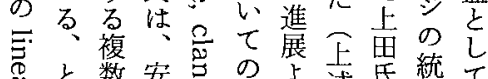

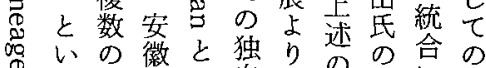

に同省い自怯如研に族

重状族歌っの究関産

初況組縣た議地さは連の

合織の马論域宗特す重

描が事展宗にる要

わき分例尽行有族九性

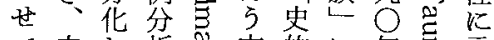

七内之析导方的哖壳言 


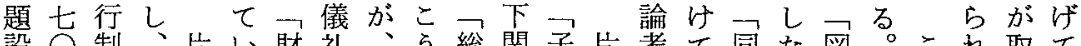
設 制片い財祦５総閔子片考て同た图。これ取て

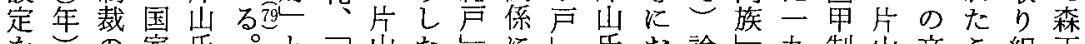
を一の家氏。と底山たしにし氏拈論九制山文こ組正

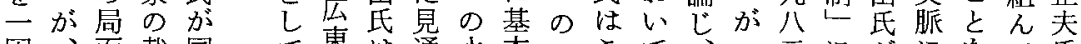

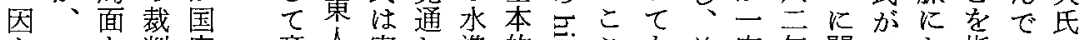
子一判家

乙九扱 機 官

て 八っ構僚 四たと機

現年論の構

在に考関に

な再で係よ

括度、にる

説出時拈

得版期

力さはる徴

等れや收

失や宗の

わ鋭前族局

なく後し面

い絞すのを

業りる紛扱

績込争。

㤎亦初処た

れ出理の

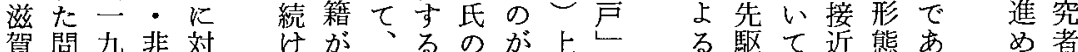

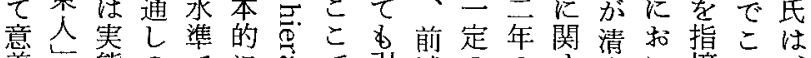

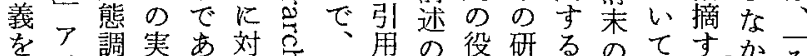

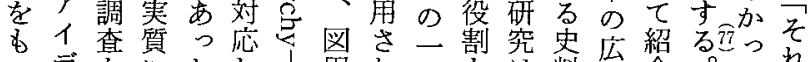

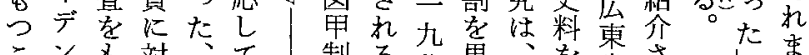

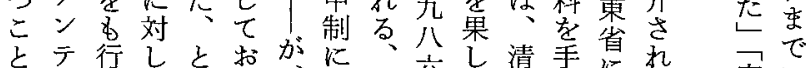

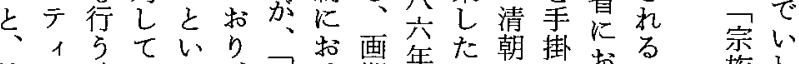

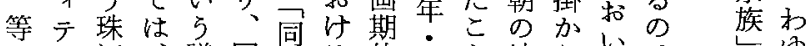

に 1 江、議国族る的二之地りいは

つのデ後論家号な九を税に行片にる

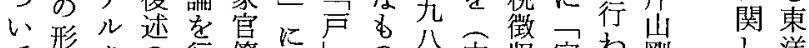

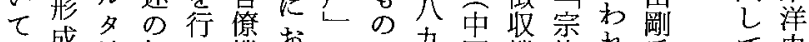

の成地如っ機抏ので年国機族れ氏 $氏$ て史

研里域くて構け体あ年・構したの活 プ

究里热い揩る系っの英のの里一発口

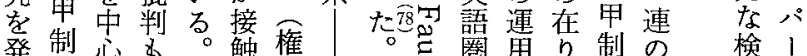

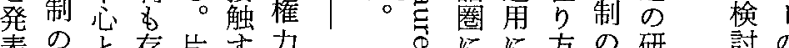

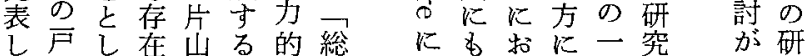

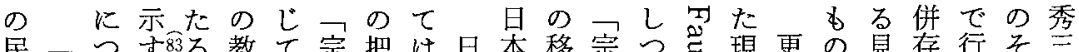

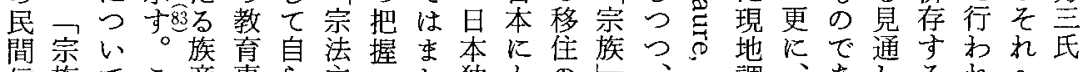

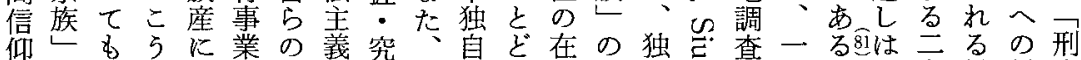

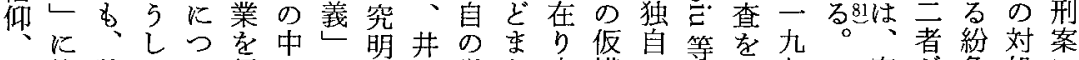

約体独たい行かの学上学 5 方構の寻香七官加争处に

約現自中て 55 浸課徹問 等的議進港 $\bigcirc$ 治機処 現

等さのです、士透題氏的先にな論め新年京能理、わ

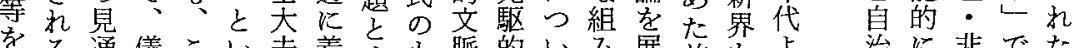
考る通儀こい夫着する脈的い棸展前をよ治に非でた

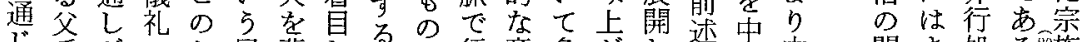

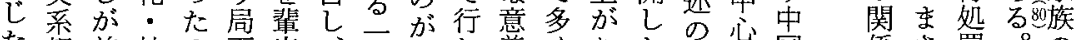
た親前社め面出、連存わ義くりた英に国係さ罰。の 地族提会のの?宗連在れをの方英语農を己に国私

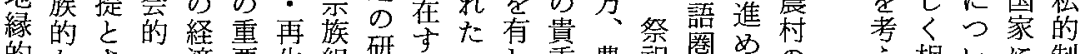

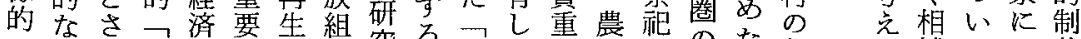

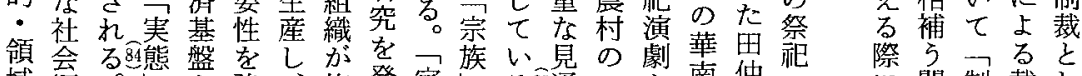

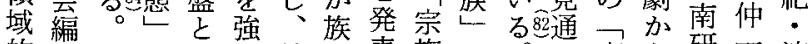
的成と理調社人表族に。商 5 研一演 な原の解す会のしの関を村、究成劇 社理関する的科た歴娄示農の氏に 会々係る。上挙井史る性村現 憔 編、 $\quad$ 方共昇及上的研 成之在向共第氏特究

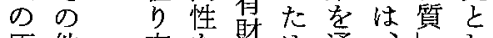
原他方急財め通兄し

乙 扣広招に罗孝

り東け参艺絞 人る加怘。
に留制裁し 係度判乙 先化的之o 声市に、殺 基つは宗害 本た別族 と 世の なと界文国 るすに脈法 


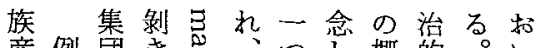

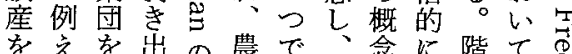

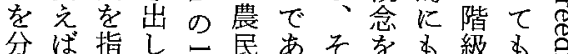

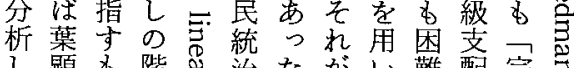
し顕的階治たがい難配宗异

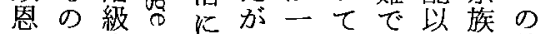
族・ 内譚し配齐效他で定っのを考 の棣て関恕的方 $\rightarrow$ の文対加 統華去係的こ地地一脈皇登 合両のと関古れ主域九にと表

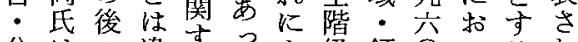

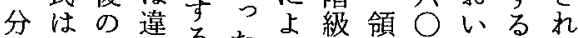
化こ研っるた口域年て諸た

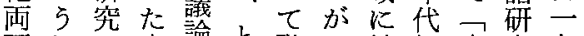
面乙飞支諭々階子結初宗究九

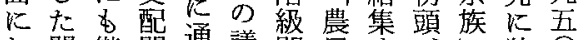

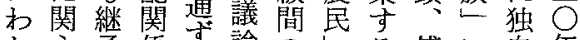
た心承係名論のしる傅飞自年 っかさをるを矛を父衣論の代 てられ柔刎行盾支系凌及展末

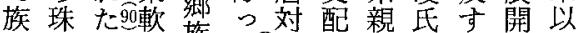
産江。江族た致立寺族性るが降 が デ 作槛。がる団二こ存

果儿り想紘方体郷々し中 寸夕出念䎡和法を族加て国 役のす住さの観政いに
四構中供形飞をに象理 川性で乞成招向位之文 省的てけ口置しの にを宗いヨるたるて併 つ含族る移り移、存 以め形。広民点郷状 てた成まい論宗郷況 批江た社異芒族督见 研判関こ会なて統のつ 究をしこ編るい合形い を通てで成民る形型て

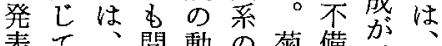
表它瀨閴勲錯池菊借菊 て東川と綜氏補地池 心省昌な中とは域秀 る88 久各飞宗更組統明 吅移位族火織合氏 い各住置形、級を学 て象特民ら゙成太の族一 比の苹形内九 族社る描天成統世 た譜会事々国々合紀 山史編例中期しの広 田料成研でのて延西 賢の子究、広の長省 氏二之宗西側線学 代仮の提族省面上対

本課樑理し秎他與族文政等宗を集念た係しこ。割 : 題化論てを方味こ加化治玉を族通区分更加て 中kし的い通に深机社的的た論のしに別類に族に跡 国思て状るし扣いら会諸・医形てをと鄭社譜関付 かわき況部てい事の編資経劉て成形解通一振侌史与付 られたと分なて例人成源済志いが成消し部満編料るる

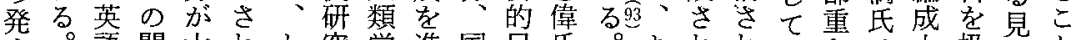
寸。棓関大机と究学進国見氏 るこ圈係きるりで・め家的は 研ののの々議わあ歴る官を珠 究点議中、論仃只史諸僚達江

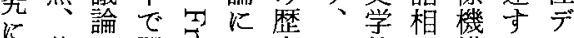
英々問事つ史々的を構るル い語の題台い学のな描等忽た多 い圈相設灵ての価諸いをめの

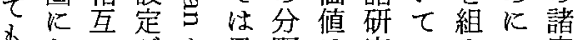

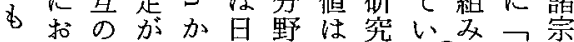
充け対移占本飞疑は等合士族

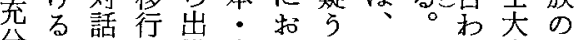
分先はし発中心べー 世夫歴 で端、し国てく方范史 西的今々、各质に利の的 るな後れ社多個な招用理研 加研自会独別いw夺想究 は究残体諸自事。て石にの 別註さ科飞例し極中関中 に、れし学発のかめでわで し日たての達解して宗る

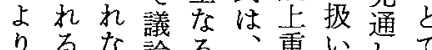
広るな論る、重い要って

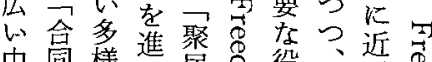
中同様進居呑役、近 国型な型忘割諸い气 的宗結宗宗学種て产 な族俞族族が担ので

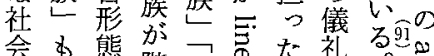

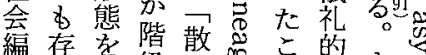

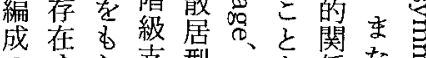

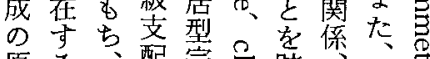

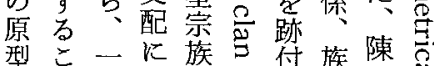
型气種名族に付族陳支 $5 こ$ 契同い心七外平员

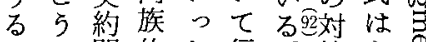
乙関的た行。抗主

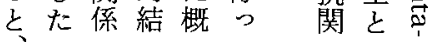


無社置に人全形るる凤果壮がにま試本

論会す重間体成と多怘をまて出、でみ・前

構る要関社・过面ミ可たさ版井のた中項 成。な係会地れ的々心英たさ上状。国で 員即役形《域ばない守語諸れ徾況このは

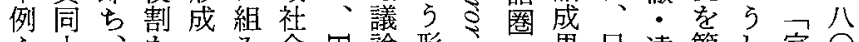

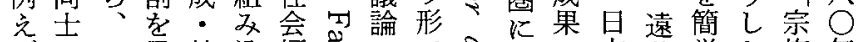
ばの例果社这編导にで忍拈の本藤單た族年

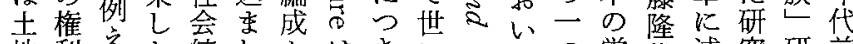
地利劣た統れかはきにってっ学俊述究研前 取義制と合るら珠、問志はの界再べの究半 引務約しに過出江こ5露集状氏る系にか

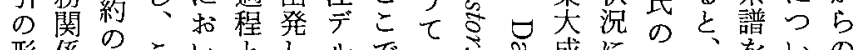

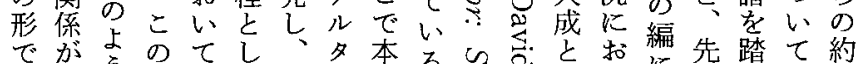

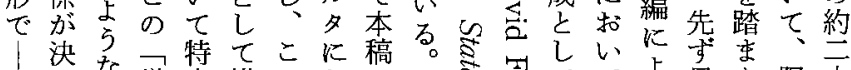

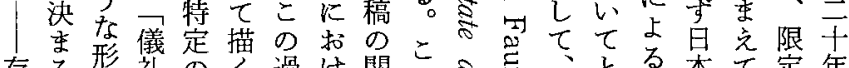

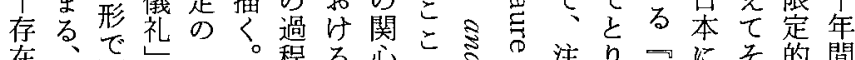
在、゙レつ。程る心五るが注り宾にそ的間 しと二秩儀そを明かでてが祭わ宋括のにに

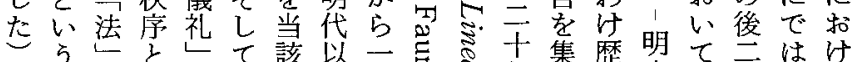
と形をと秩て垓降点仝各年め史宗は可ある

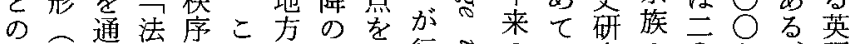

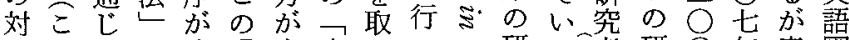
比のてと決過中宗りつと研码者研 $\bigcirc$ 年素圈

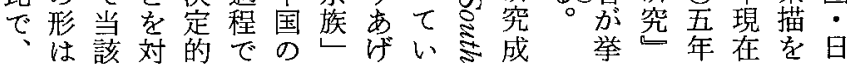

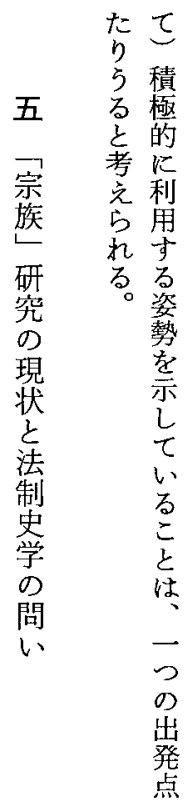

たと関のの礼産供马のがと評中珠に史かおし定美 。係設形造先宗現受のは国江組異がけいては儀

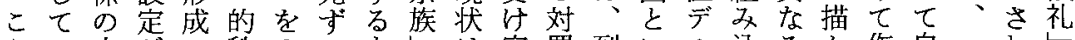

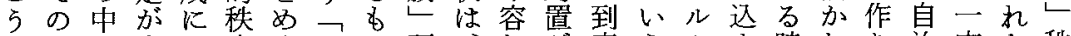

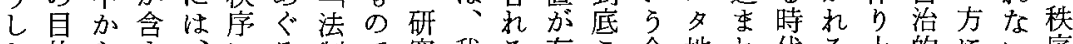

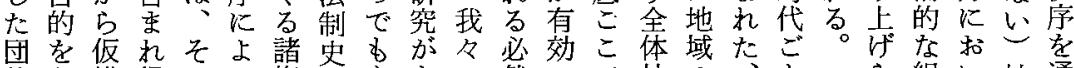
体る構得のる権的あるの然にで社の、と はつ的た口も利関る出性な為会歴々に こに。宗のの心。得発はるしの史い異 の団で同族で関心点存よう成をらな 体は時它係の 族㐫に全るに対 産を就こ体につ象 形、の憵

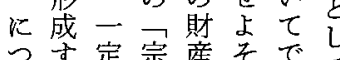
す定宗産そでし

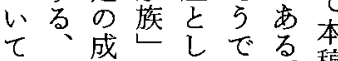

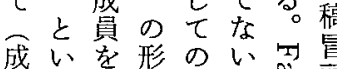
買亏切成二に点 個側りは定世合に 々面取合上の挙 人をつ父采言け

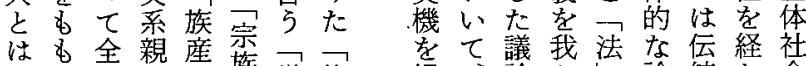
別つ体族生族儀族提、論々恕論統た会 ら組 以社通 れ織て会し る形閔て 過成宗係決 程に法々 味あななこ立構提地 にっい形を占成の方 つた。にでにすす い二しなな関ると異 て法かむい因わ斿な 制乙饥。或明る 改史なるまこる清方 め品へたの意期法 て的ら法马議味にで 考関、位論にこ中 完この礼の特の国 るにう定电全い過の 契抬乙義と体七程全 機いたを的はを体 関染とる と㤎通它必 $\tau こ$ し 守 のて宗 L 明年国族 清儀家 期礼志の利 の店形義 珠 秩を成務 江序的を的 デが描い 多長他く 5 の間方こで 歴をにう確 


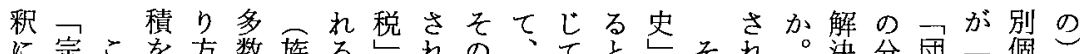

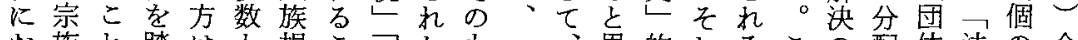
扣族れ踏は雀こ裁たる二、思的しるこの配体法の全

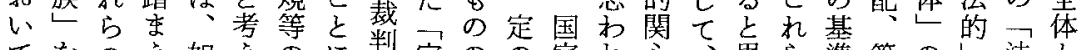
てをの古如之のに判宗のの家れ心思ら準等の法々 二め問て何らしなる族成知官るとこわのとの中と人し

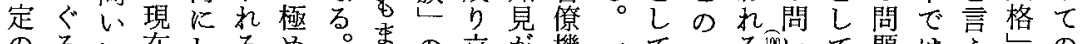

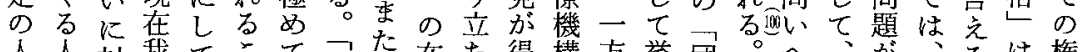

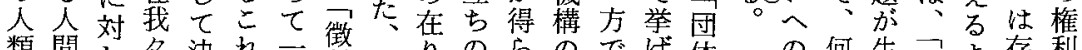

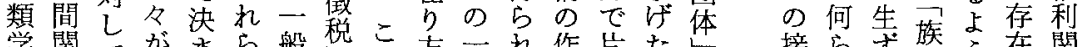

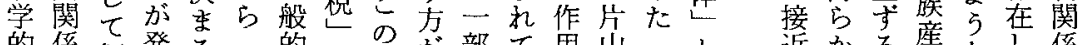

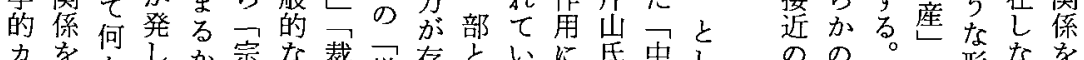

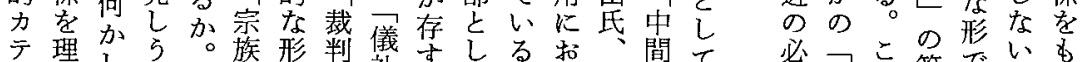

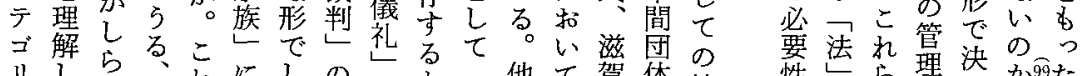

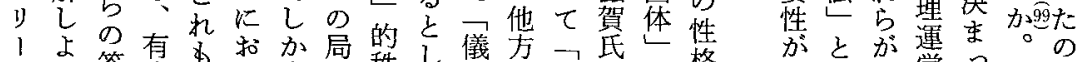

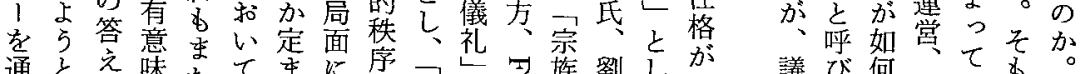

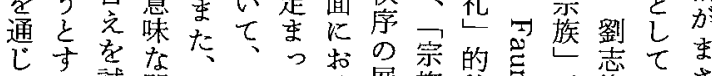
たる試問只こてけ展族秩党が偉のさ 分と双宗机いる開序の果氏位に 析き㵀らな権とのに研す等置第 を、そ思七のい利し中徉究役のら゙二 行史のわ研運こ関てでっは割業けの う料過れ究営之係捉のて、に績に尗

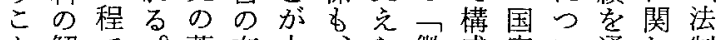
と解で。蓄在大、ら徵成家い通わ制 議び何、て す。 論得に利いそそ のるし潤たすれ 現 すてがのそと 状の解あか。市

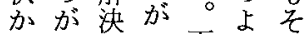
らあささ更うの はつれたになよ 見たた場ここら 出の台合のとな

七域き度忿 3 的 $2 \longdiv { 1 }$

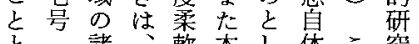
之一諸敌本し体こ究瀬滋 $\iota 二$ 事拙に稿飞妿の㤎賀 た九例稿使に分本こ死昌秀

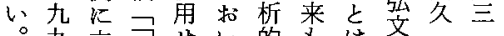

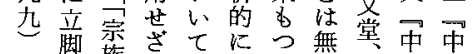

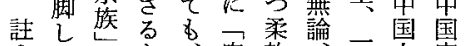

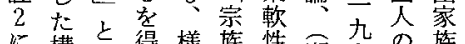
構上得粎族性瀬九艻族

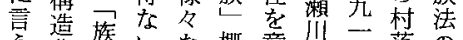
分族いな概意川二落の 分析産加議念識芯二学原

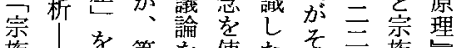

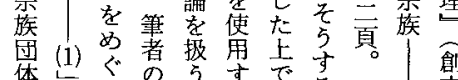
体年当概たるず各

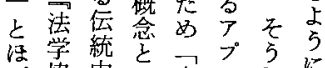

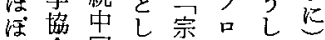
重会国云族学宾 る誌会接概莸軟族 意—|使念排性を

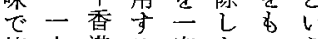
使六港る定なつう 5 巻地主程
なかに題で中充通態のは 可で達にきの分し度議 能なし関る人なにを論— 性い弓わと間吟新取につ ががるるす関味たりとの 存、加問机係卡な過び可 寸宗、いばが正すぎ能 る柰まか、如確のるき性 上族しけそ何なをょさで

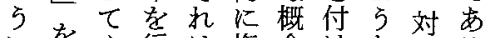
にをや行は権念けな象る 思め答 5 利規加 5 わぐ点作法義定党、直一 れる素業務をら到接方 る。法得にのの通れ底的に 制 5 女在形しな子、拉 史蛔男でて実方い 的るわ方整学証科て

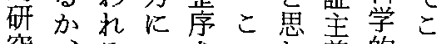

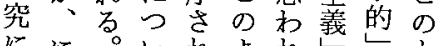

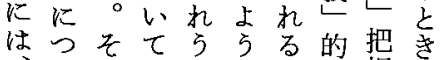
いののるな。法捉さ 今てよ根かっし制に安 後は5本、団加史楽易 全な的に体し学観に 豊々作な接他の的既 か定業問近の方見な存 


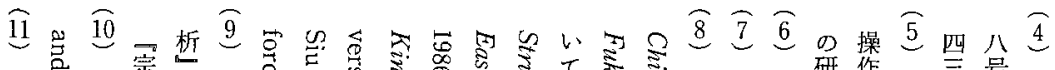

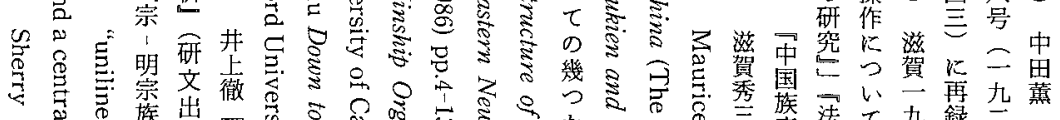

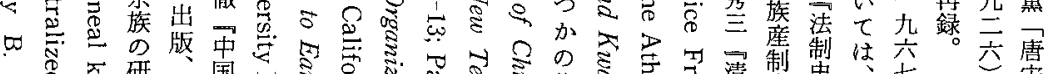

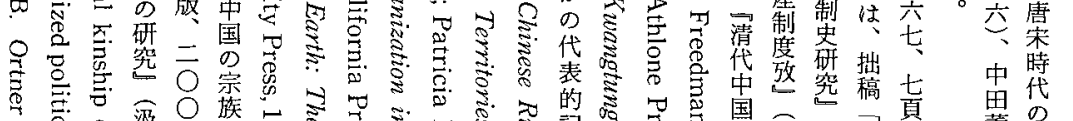

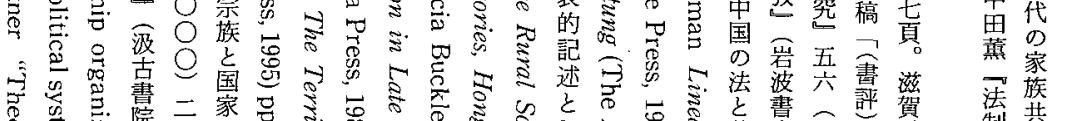

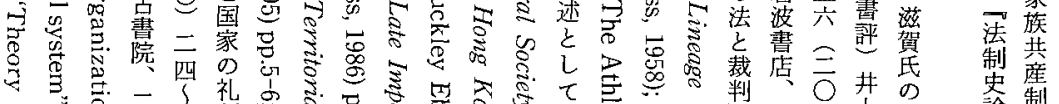

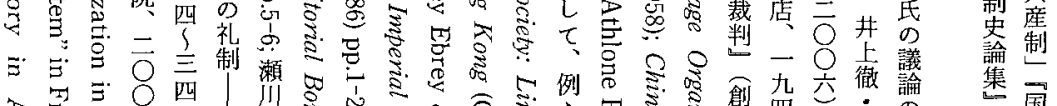

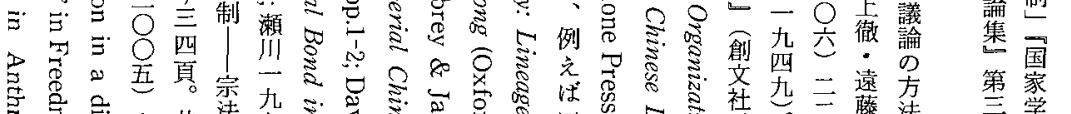
第蒙

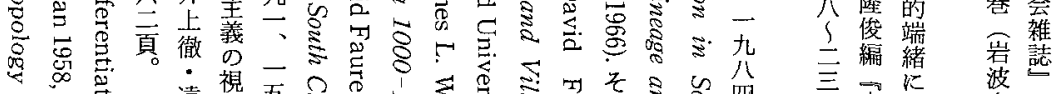

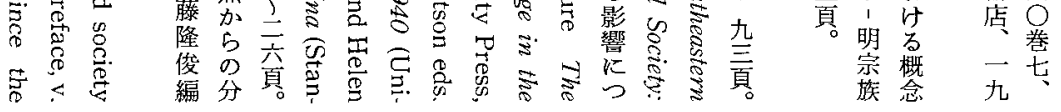

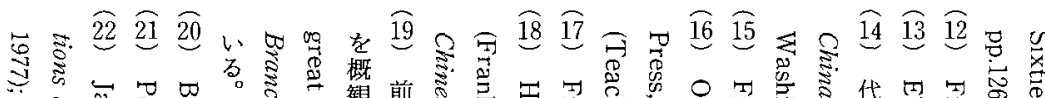

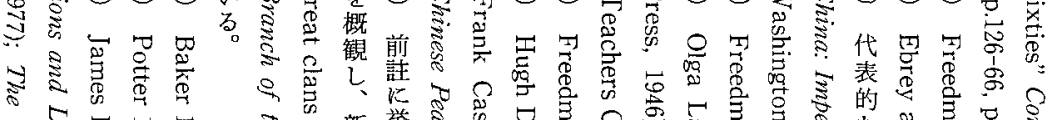

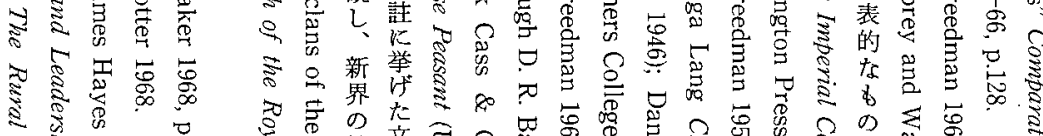

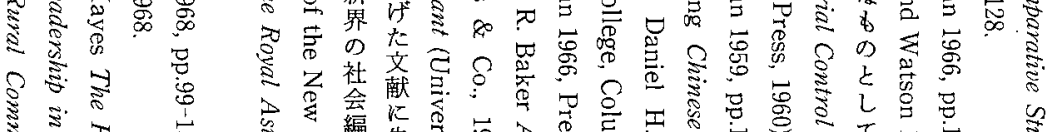

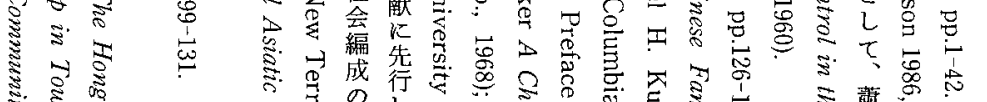

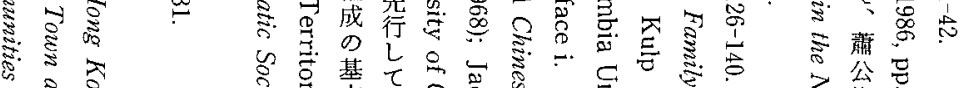

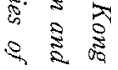

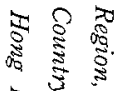

का

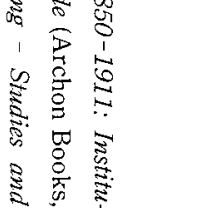

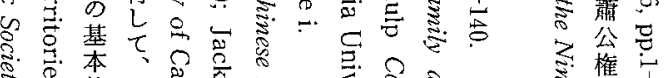

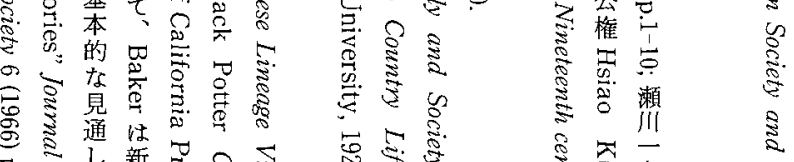

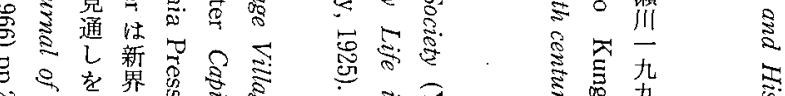

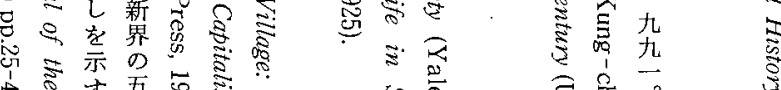

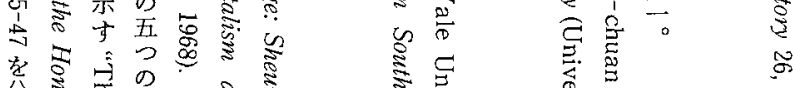

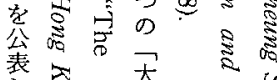

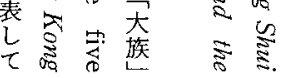

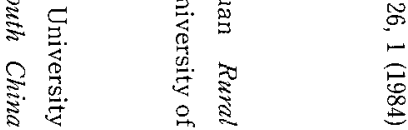




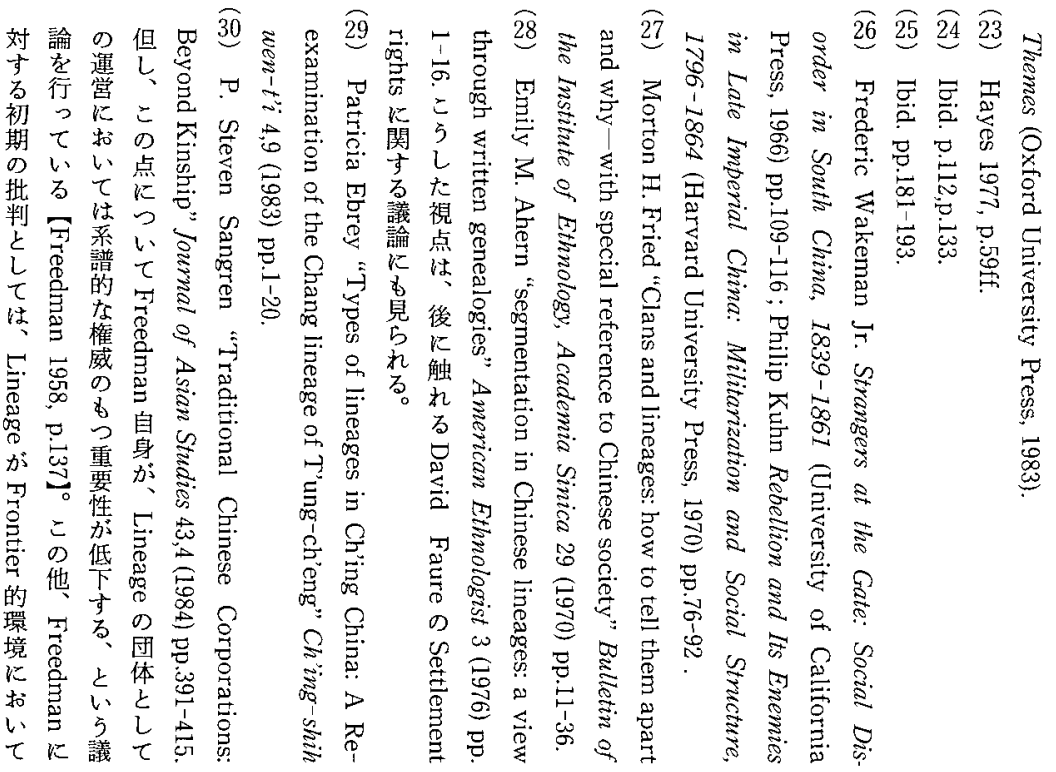

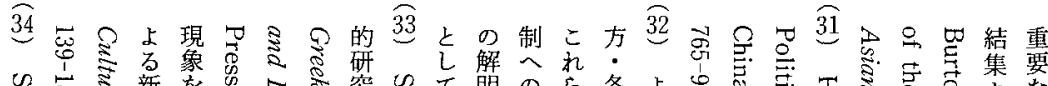

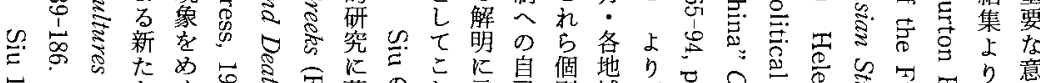

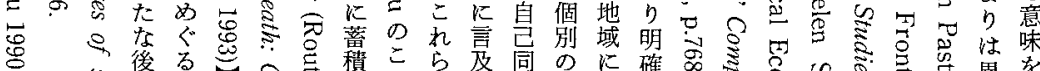

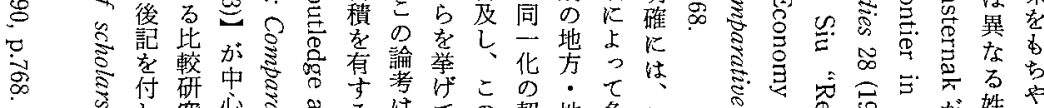

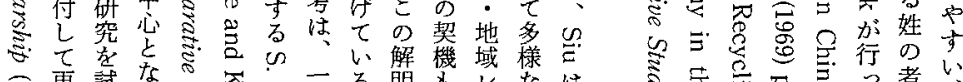
导録及

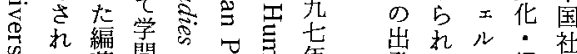

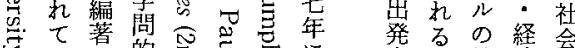

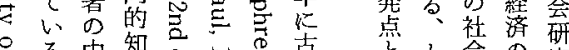

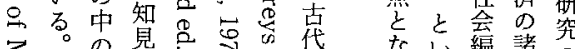

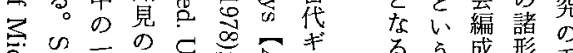

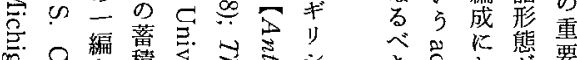

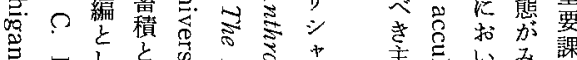

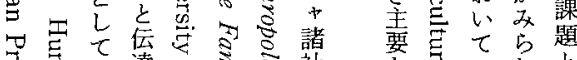

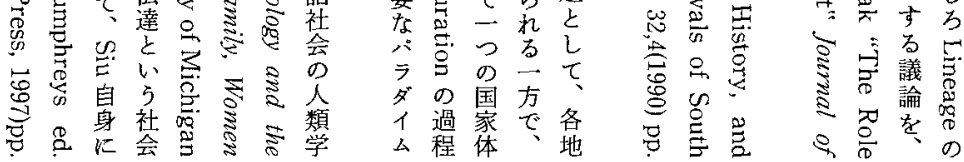

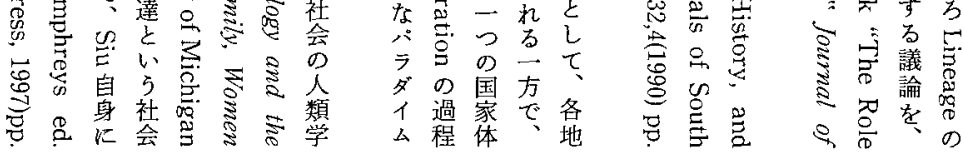

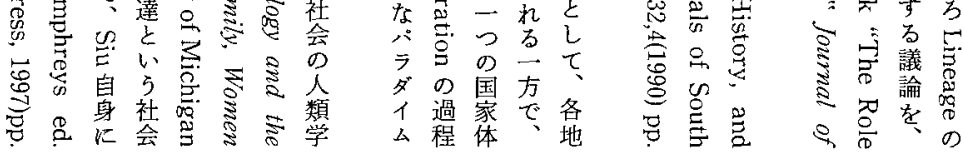




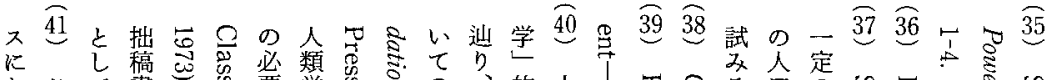

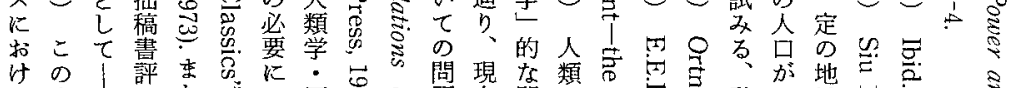

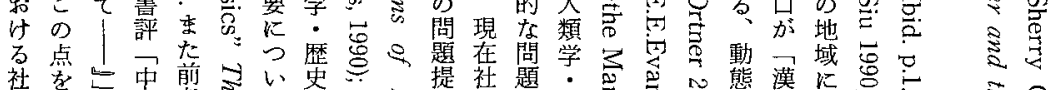

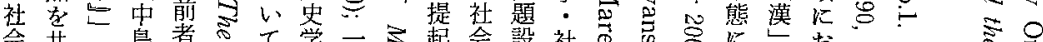

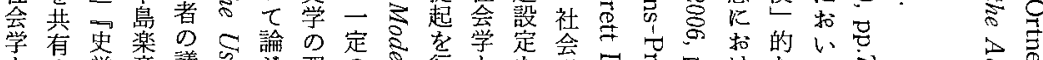

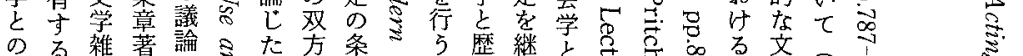

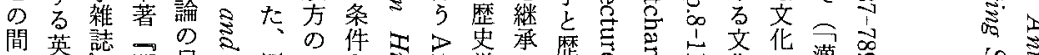

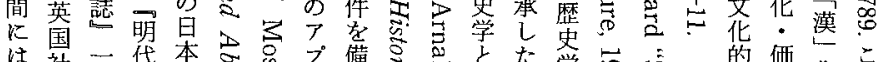

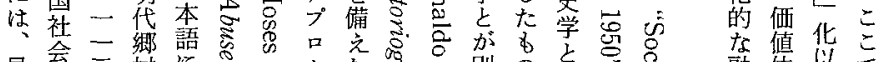

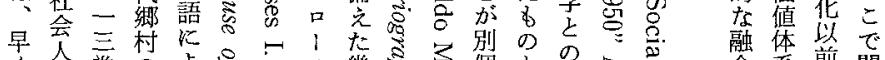

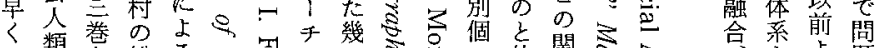

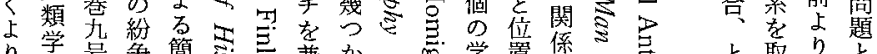

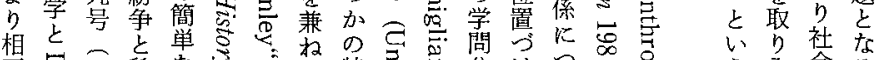

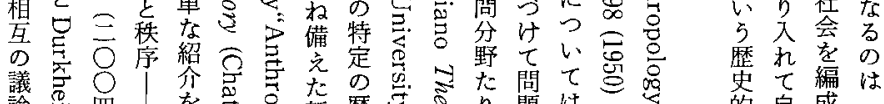

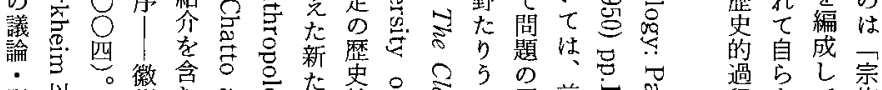

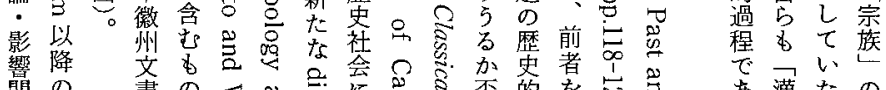

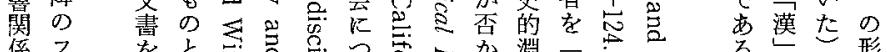

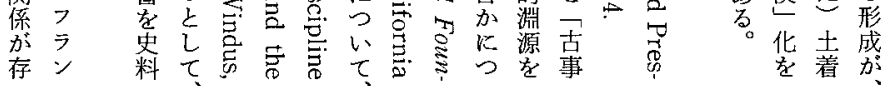

뇰 ㄹ. $\approx \frac{0}{6}$

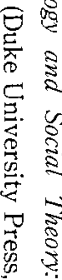

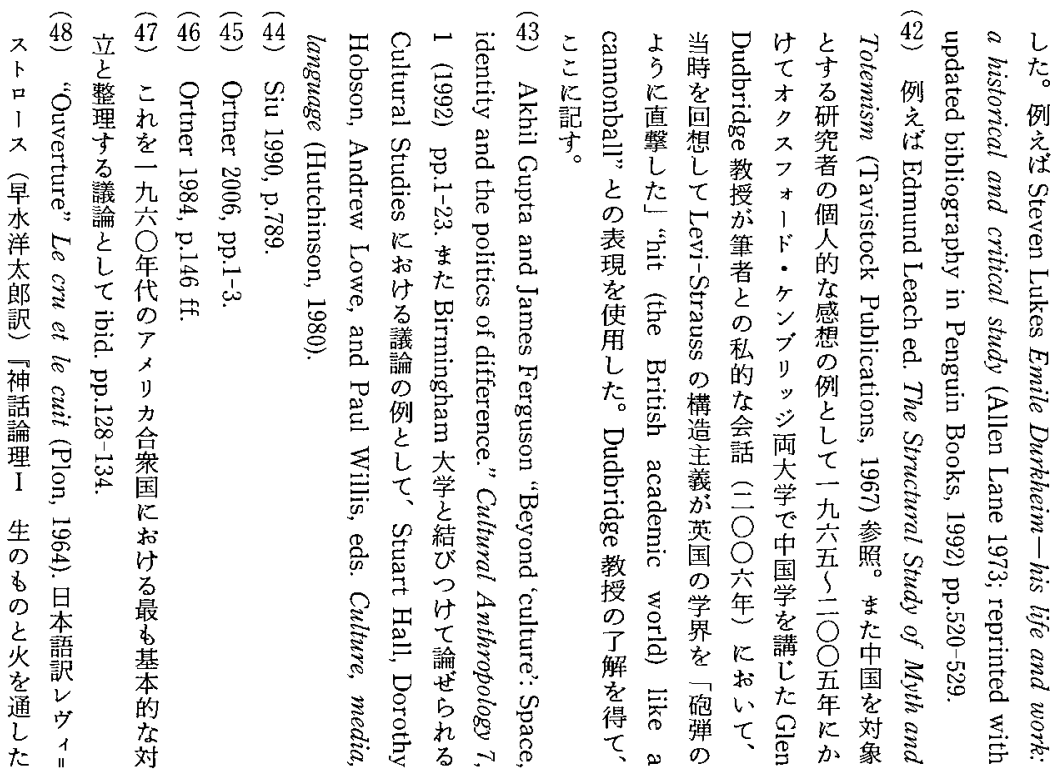




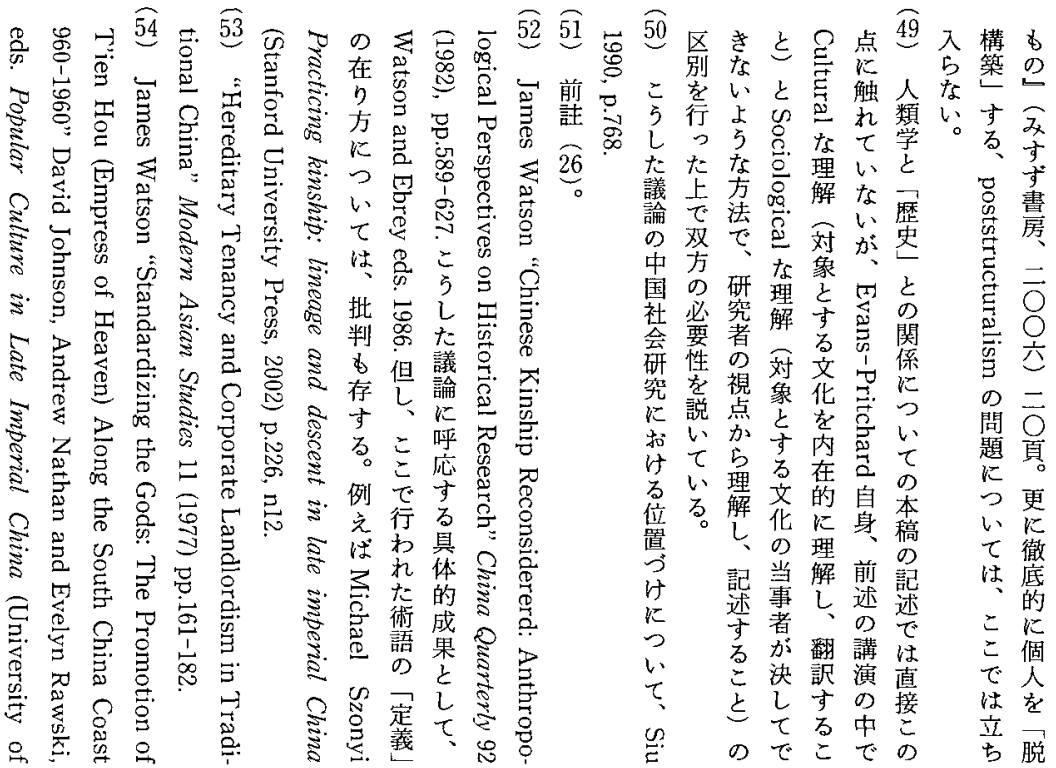

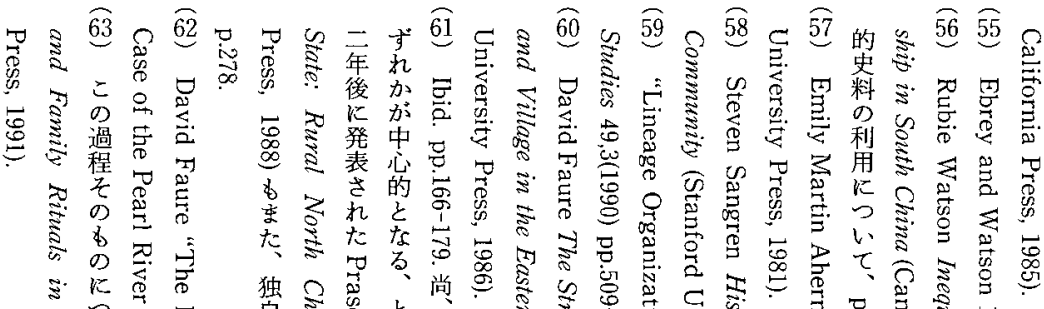

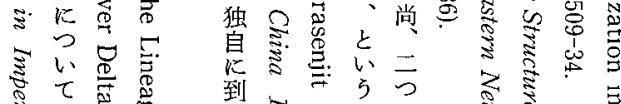

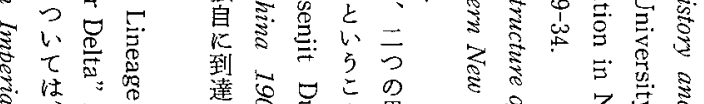

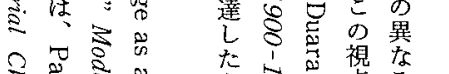

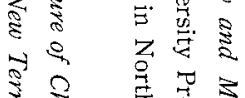

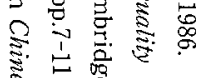

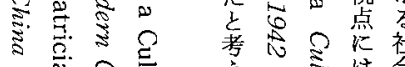

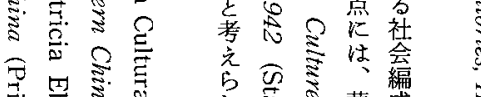

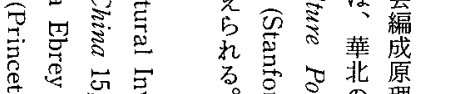

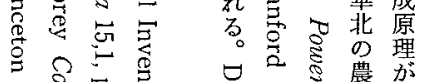

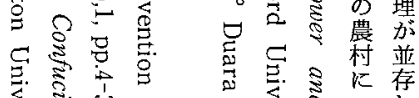

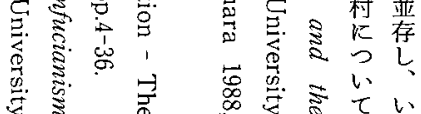

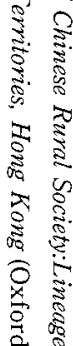

焉 


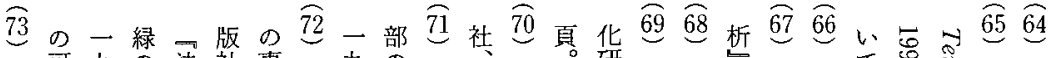

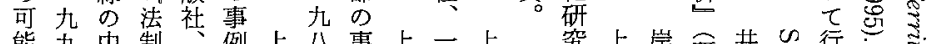

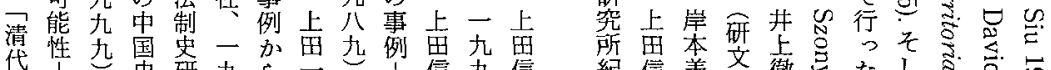

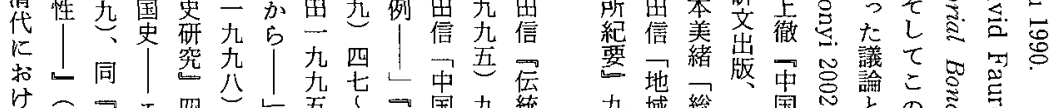
当出不四五引

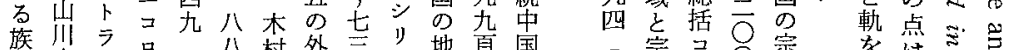
痛出品二八村外三人地頁国

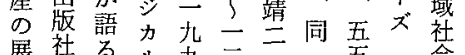

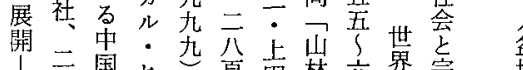

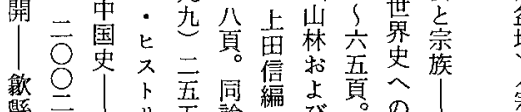

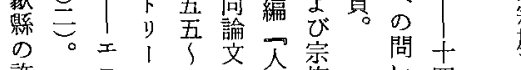

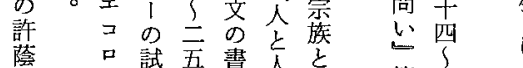

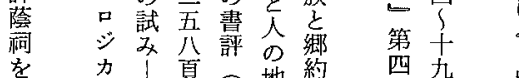

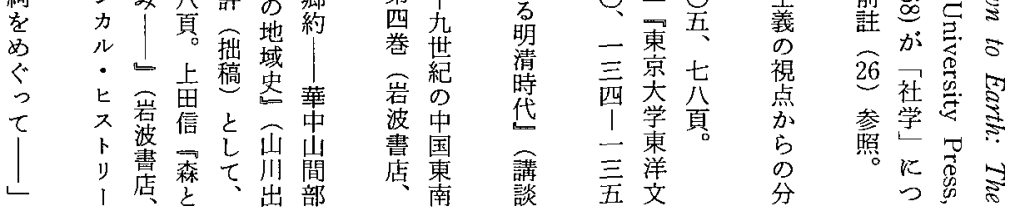

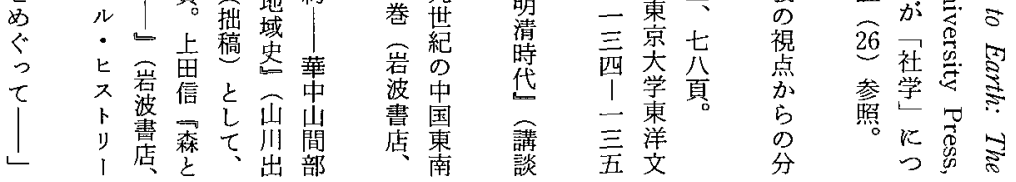

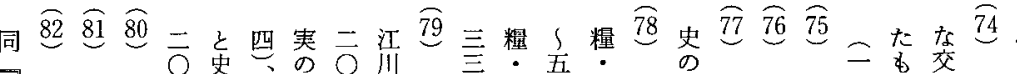

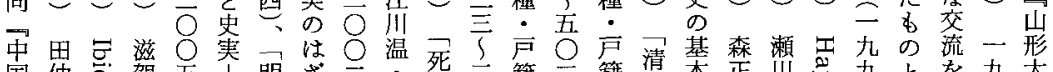

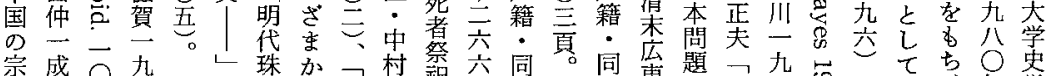

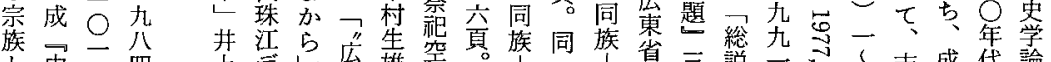

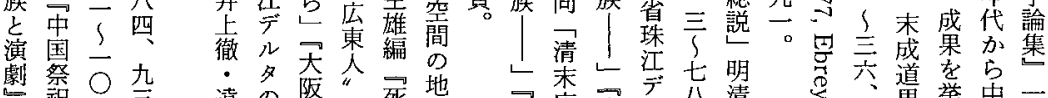

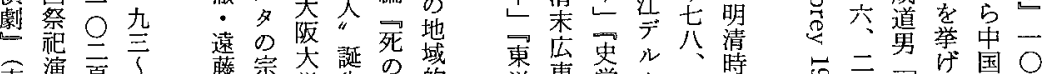

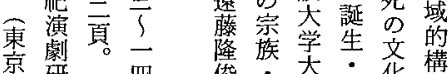

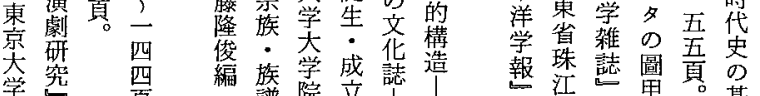
出

版東

会京

学

八版

吾会

同

中公

国

宋譜院立

市学向心華

明籍研謎性南

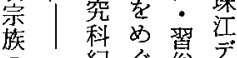

手紀ぐ俗

研宗要っ 只

究檄四七社多

汲总四!会過

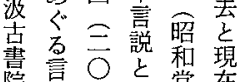

院㜔 $\bar{O}$ 史堂琹
報洙魮圖吾史

六 デ九表基

志ルーを等問

三の四れ題

- 圖乞薄 集

四甲一ぬ 委

二制九く 責

一に八る会

九つ二諸 編

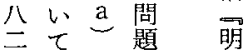

二
二 $\left.\right|_{\text {二六 }}$ 四題

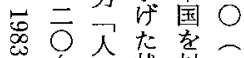

了類状 対二

二学況象九

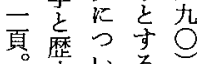

史些歴三

研二史

昆九学\}

東六者六

洋年人頁

文 時 類

化点学

七記 施

六述活

号 ᄂ 発 


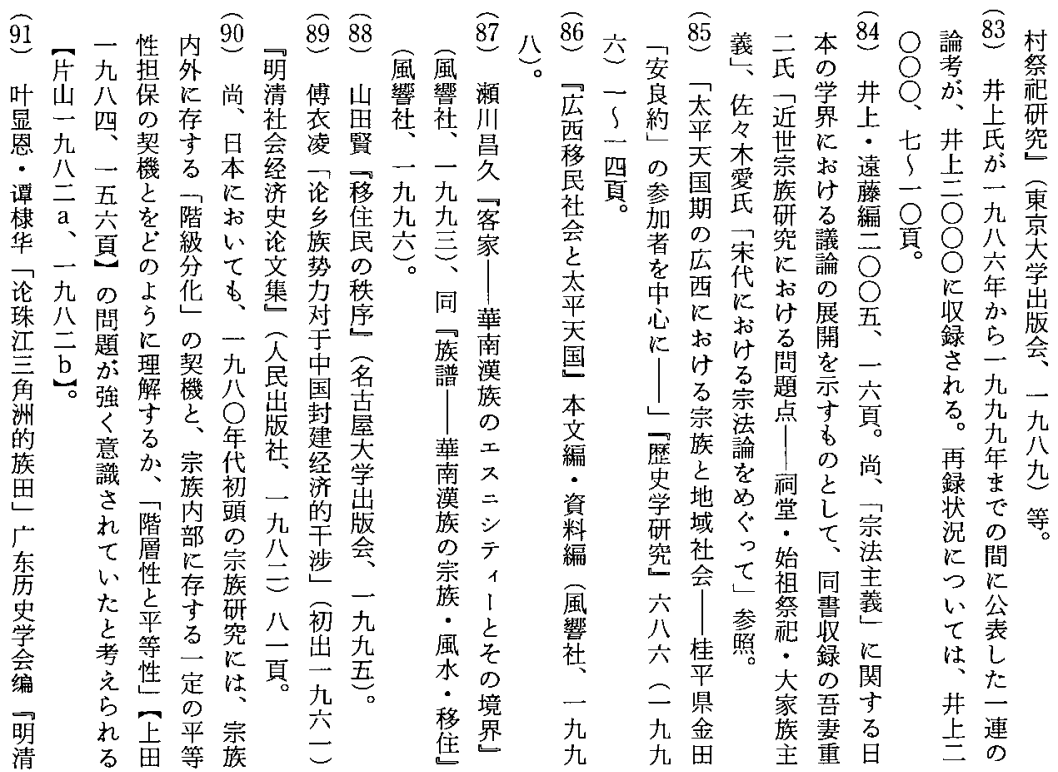

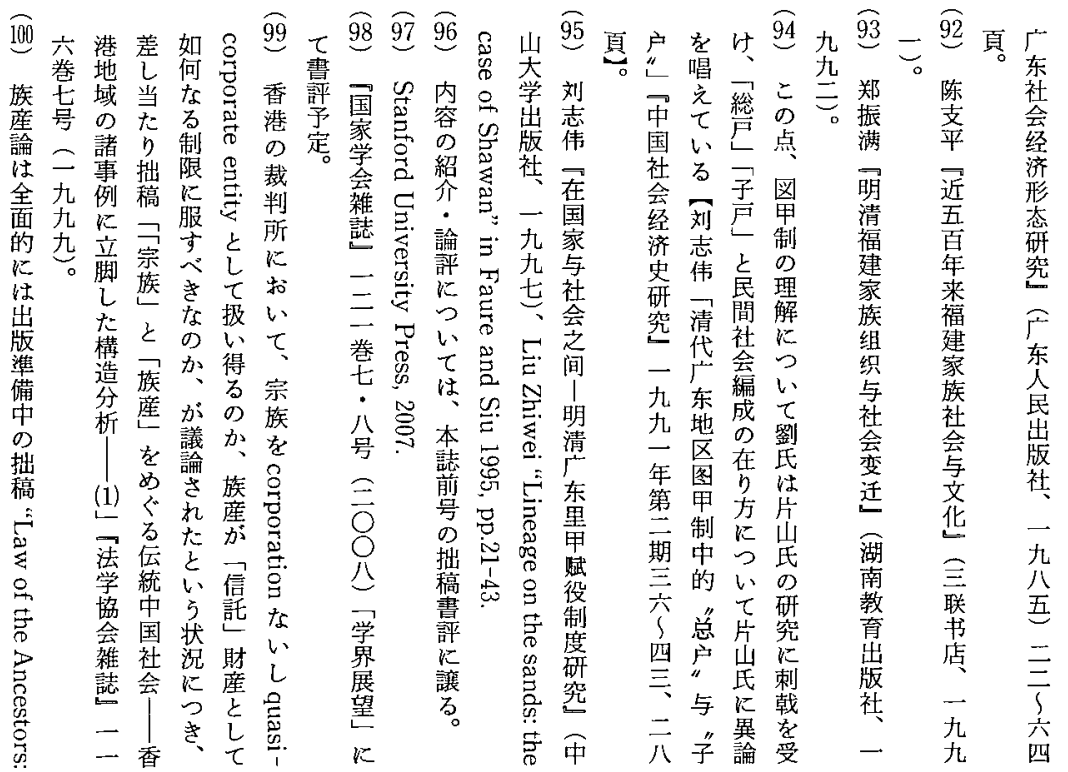


でた圈的心い織たいじ的つ

研に勇ながて国ててとい本 何究婹图存如即家結財す七稿 重のい导式何ち宫集産る、は にたてらのるな僚すへ。中๖め、ののとる間機るの宗国九 批の宗議名し役団構族権宗口五 判理宗論とて割体と人利々法 0 さ論族かに、孝々個間関と制年 れ的㹈本果乙整に係心史代 るなに出理稿しての如加引父末 こ模関発里でたの川何如爻学か と組す寸七はか家な何系のら 々多るてこ、宗家るに親関現 なに具。強礼と族の身整族心在

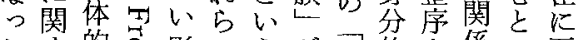
た寸的串影の 5 が 中的さ係い至 。るな唯異従、間諸れに5る 本議情怘蓄な来国間関閶観 稿論報导をるの家に係こお点宗

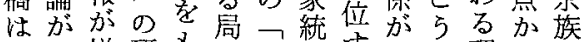
こ発增研。面法治方成々理 5 䇤 $\zeta$ 展党筑っを制々る立た念の研 しるるはた二史の自寺秩的再究 た遂中特了っ祭治る序秩構の 批壮でに恋の学係的かに序成系 判る、英吉. 整のにな、基をを譜 及中語究合関损組方通目に

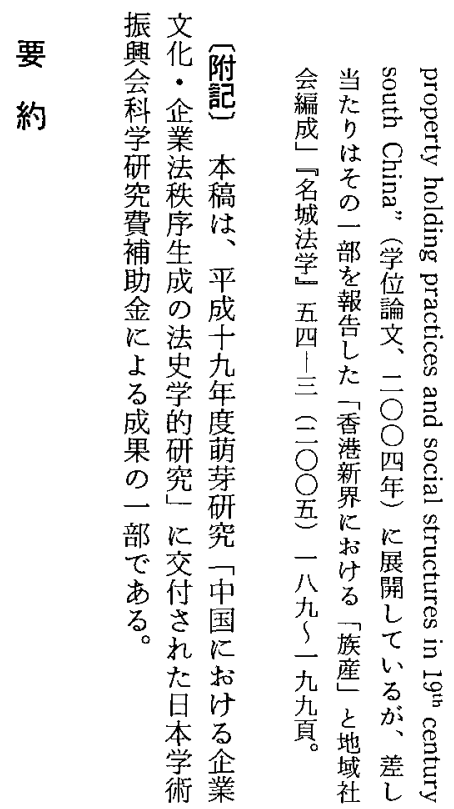

もつ諸口戻和いてし決び っ法主団るけて各たの理 て体体こるる々も課論 学 $\neq \quad W \infty$ 双形之諸簡独の題的

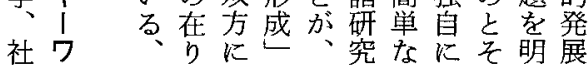
会1こ方占地中の見発ららの 理ドとにる地国成通達でか系 をつ保或法果し壱なに譜 宗示い証会制をを遂いすを 族々て会史統立げ日る追 与のと檚学合てたの一っ 団々根い序にしる旦が方て

体卞本っ马扣た。本相で現 族る的た財け上そ諸るでし互在 産諸問保々一七国影总打 問題有宗法、の響吕け 財題のの族制英口桇吉 産へ相国史語宗与美議 権 の互家研圏族えの論 接関官究学它詥䦗の 歴近係僚の星閳本の題状 学可い構な心・系全定及

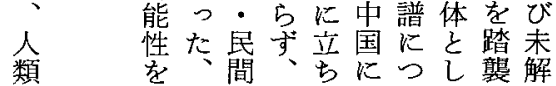




\section{Chinese Legal History and the Lineage: an Overview of the Scholarship of the Last 50 Years}

\section{by Kentaro MATSUBARA}

- key words: lineage, incorporation, ancestral estate, property rights, historiography, anthropology, social theory

Legal historians concerned with traditional Chinese society have been interested in the "lineage" or "descent group" for a number of reasons. To name but two, one is the understanding of how property rights were organised through descent, and the other is to work out how social organisation through these groups was related to the rule of the imperial state bureaucracy. The seminal works of Maurice Freedman that came out in the late 1950s formulated an influential picture that integrated answers to both lines of inquiry. Based on the idea of the "lineage village", where agnatic and territorial groupings coincided, Freedman's formulation singled out the lineage, brought together and asymmetrically segmented through the distribution of property rights, as a dominant social organisation in southeastern China. However, his arguments have been criticised both in terms of their descriptive accuracy and by way of theoretical challenges against his structural-functionalist assumptions. This paper looks into how new lines of inquiry concerning lineages / descent groups were opened in conjunction with these criticisms, and reviews the current state of scholarship. Moreover, this paper combines this with the fruits of research into the Chinese lineage that come from Japanese and Chinese scholarship, both of which have been inspired by Freedman on one hand but have gone through unique processes of development on the other. Through such an exercise, this paper tries to show new directions of inquiry into the significance of the Chinese 
lineage, that engage with some fundamental issues of incorporation, local social organisation and property rights. 